\title{
7
}

\section{Pneumocystis jirovecii Pneumonia in AIDS Patients}

\author{
Jose M. Varelaํ, Francisco J. Medranoํ, \\ Eduardo Dei-Cas 2,3 and Enrique J. Calderón ${ }^{1}$ \\ ${ }^{1}$ Instituto de Biomedicina de Sevilla and CIBER de Epidemiología y Salud Pública, \\ Internal Medicine Service, Virgen del Rocío University Hospital. Seville, \\ ${ }^{2}$ Parasitology-Mycology Service (EA4547), Centre of Biology Pathology, Lille-2 University \\ Hospital Centre, Faculty of Medicine, Univ. Lille Nord de France, \\ ${ }^{3}$ Biology \& Diversity of Emerging Eukaryotic Pathogens, Institut Pasteur de Lille, Lille, \\ ${ }^{1}$ Spain, \\ 2,3France
}

\section{Introduction}

Pneumocystis pneumonia (PcP) in humans is caused by the opportunistic eukaryotic pathogen Pneumocystis jirovecii (previously known as Pneumocystis carinii f. sp. hominis), which has recently been reclassified as a fungus because its cell wall composition and gene sequences (Edman, 1988, Stringer, 1989). This atypical uncultured fungus remains a major cause of illness and death in patients who have HIV infection. PcP has been the most common AIDS-defining opportunistic infection in the United States and Europe during more than two decades. Before $1989,60-80 \%$ of AIDS patients presented with $\mathrm{PcP}$, and the infection was estimated to be the cause of the death of $20-25 \%$ of these patients (Dei-Cas, 2000). Nowadays, despite the introduction of Pneumocystis chemoprophylaxis and advances in the treatment of HIV infection, mainly the development of highly active anti-retroviral therapy (HAART), PcP remains as a major opportunistic infection in patients with AIDS. While, the incidence of $\mathrm{PCP}$ among individuals with HIV infection has decreased in developed countries, the prevalence of AIDS-related PcP in developing countries remains high and poorly controlled. AIDS-related PcP continues to be an overwhelming illness among individuals who are unaware of their HIV infection, those without access to antiretroviral therapy, among patients who are intolerant or nonadherent to therapy, those who do not comply with prophylactic medications and in cases of failure of prophylaxis, probably relate to the emergence of drug-resistant strains (Calderon, 2010b).

\section{Epidemiology}

Pneumocystis jirovecii is probably one of the more frequent infectious agents faced by humans in everyday life. Today, it is recognized as an extracellular, obligate, host-specific, yeast-like parasitic fungus virtually restricted to lung tissue that can be directly transmitted among susceptible hosts by the airborne route. It is established that human PcP in not a 
zoonotic disease, and this notion has important implications for the epidemiology of $P$. jirovecii (Calderon, 2009). Although early studies reported the isolation of Pneumocystis DNA from the air surrounding apple orchards and the surface of pond water, no Pneumocystis forms were identified in environmental samples by microscopic analysis, and it is uncertain whether there is an ecological niche for Pneumocystis outside mammalian hosts (Wakefield, 1996). Animal sources of P. jirovecii can be excluded, because the Pneumocystis organisms that infect mammalian species are characterized by strong, close host-species specificity (Aliouat-Denis, 2008). Thus far, the human being is the only known reservoir host for $P$. jirovecii, and humans probably acquire the infection only from other humans (Calderon, 2009).

Serologic studies have shown that specific serum anti-Pneumocystis antibody can be detected in most children early in life, indicating frequent exposure to this organism (Respaldiza, 2004). On the basis of this finding, disease in immunocompromised persons has long been thought to result from reactivation of latent infection acquired in childhood. However, animal and human studies have shown that elimination of Pneumocystis often occurs after infection, implying that the persistence of latent organisms is limited (Morris, 2002). Recent demonstration of $P$. jirovecii transplacental transmission may explain the accumulating evidence that the primary infection is widely acquired very early in the life and support the commonly held view that human infants are a major natural reservoir for $P$. jirovecii, since they can remain colonized as their immune response matures (Montes-Cano, 2009).

Colonization with $P$. jirovecii in adults has recently gained attention as an important issue for understanding the complete cycle of human Pneumocystis infection (Calderón, 2010a). In general, colonization is defined as isolation of an infectious agent that does not result in sufficient damage to cause clinical disease, but that may alter host homeostasis. In the specific case of Pneumocystis, colonization is currently defined as the detection of the organism or its DNA in respiratory samples from subjects without signs or symptoms of pneumonia (Morris, 2008).

Among adults, Pneumocystis colonization has been well documented in both HIV-infected and non-HIV-infected individuals, and certain populations appear to have a higher risk of colonization. Studies have shown that individuals who have an underlying HIV-infection or another cause of immunosuppression and those who are not immunosuppressed but have chronic lung disease may often be colonized by P. jirovecii (Calderón, 2009). These groups at risk for carriage probably represent a major species-specific reservoir of infection, although transient Pneumocystis colonization has been also identified in healthy individuals that could behave as a sort of dynamic reservoir for future Pneumocystis infection in other susceptible subjects (Medrano, 2005).

Several outbreaks of $\mathrm{PcP}$ have been reported in hospitals. Molecular analyses of Pneumocystis in some of these studies suggested nosocomial acquisition of the infection (de Boer, 2007, Olsson, 2001, Rabodonirina, 2004). In addition, Pneumocystis colonization has been found more frequently in health care workers in close occupational contact with patients with PcP than in those who had no occupational exposure (Vargas, 2000, Miller 2001). On the other hand, a recent study has provided molecular evidence that airborne transmission of $P$. jirovecii from colonized immunocompetent carrier hosts to susceptible persons may occur (Rivero, 2008). Therefore, interindividual airborne transmission seems to occur in humans in both hospitals, as a nosocomial infection, and in the community. 


\section{Pathogenesis}

Basic knowledge on Pneumocystis has been hampered by the lack of a reliable in vitro culture system. However, through the use of molecular techniques and experimental models of PcP in immunosuppressed animals, many progresses have been made over the last decades in our understanding of the complex pathophysiology and pathogenesis of this fungal infection.

At the histopathological level has been shown that the proliferation of Pneumocystis is accompanied by anatomical and physiological changes. In animal models, alterations in alveolar-capillary permeability are followed by degenerative changes in type I pneumocytes, restorative hypertrophy of type II pneumocytes and diffuse alveolar damage leading to pulmonary fibrosis (Walzer, 1993). Studies in humans have also shown changes in the permeability of the alveolar-capillary membrane, pulmonary diffusing capacity and vital capacity in total lung (Coleman et al., 1984). These changes depend on the ability of Pneumocystis, demonstrated in animal models to induce in the very early stages of the infection alveolar macrophage activation, increased pro-inflammatory cytokines and changes in pulmonary surfactant even when small amounts of microorganisms are present (Prevost et al., 1998).

In the infected host, Pneumocystis organisms dwell almost exclusively within lung alveoli. Within some hours after experimental intra-tracheal infection, Pneumocystis trophic forms attach to the alveolar epithelial cells. The host immune response against the infection involves complex interactions between CD4+ and CD8+ T-cells, alveolar macrophages, neutrophils and soluble mediators that facilitate clearance of the infection. Disease only occurs when cellular and/or humoral immunity is defective.

\subsection{Interactions of Pneumocystis with alveolar host cells}

Trophic forms adhere tightly to alveolar type I cells through interdigitation of their membranes with those of the host. The binding of Pneumocystis to the epithelium is facilitated by interactions with proteins of the alveolar fluid, such as fibronectin and vitronectin that bind to the surface of Pneumocystis and mediate the attachment to integrin receptors present on the alveolar epithelium. In infected tissues, type I alveolar cells with adherent Pneumocystis appear vacuolated and eroded (Benfield et al., 1997). However, studies of cultured lung epithelial cells have shown that the adherence of Pneumocystis alone does not disrupt the structure or barrier function of alveolar epithelial cells, although proliferative repair of the epithelium is reduced. It is therefore unlikely that the adherence of Pneumocystis to alveolar epithelium is by itself responsible for the diffuse alveolar damage in severe pneumonia (Benfield et al., 1997; Thomas \& Limper, 2007). Rather, the inflammatory responses in the host are primarily responsible for the compromise of the alveolar-capillary surface (Thomas \& Limper, 2007).

Electron microscopic studies have shown that Pneumocystis organisms are embedded in protein-rich alveolar exudates, which contain abundant fibronectin, vitronectin, and hydrophilic surfactant proteins A and D. In contrast, hydrophobic surfactant protein B and $\mathrm{C}$ are reduced during PcP. Both surfactant protein A and surfactant protein D interact with the Major Surface Glycoprotein (MSG) components of the surface at Pneumocystis. Surfactant protein A modulates the interactions of Pneumocystis with the alveolar macrophages. In contrast, surfactant protein D mediates the aggregation of the Pneumocystis organisms, but because the aggregated organisms are extremely poorly taken up by macrophages, they may escape elimination. Pulmonary surfactant phospholipids, which contribute to the low surface tension in the alveoli, are reduced during $\mathrm{PcP}$, and abnormalities in the composition 
and function of the surfactant are the result of the host's inflammatory response to Pneumocystis, rather than direct effects of the organisms on the surfactant components (Wright et al., 2001; Thomas \& Limper, 2007).

\subsection{Innate immunity (alveolar macrophages and neutrophils)}

Although parasite attachment to lung epithelial cells is essential for Pneumocystis infection and propagation, invasion of host cells does not occur (Krajicek et al., 2009). Alveolar macrophages are the first line of host defence to control the infection, since they are the principal phagocytes mediating the uptake and direct degradation of both trophic forms and cysts forms in the lung (Kelly \& Shellito, 2010). Macrophages display several potential receptors for glucans, including CD11b/CD18 integrin (CR3), dectin-1, and toll-like receptor 2. The activation of macrophages by Pneumocystis is augmented by host proteins such as vitronectin and fibronectin that bind the glucan components on the organism (Vassallo et al., 2001). When there are not opsonins in the epithelial-lining fluid, the uptake of Pneumocystis is mediated mainly through the macrophage mannose receptors, patternrecognition molecules that interact with the surface mannoprotein, MSG (also called glycoprotein A). After they have been taken up by macrophages, Pneumocystis organisms are incorporated into phagolysosomes and degraded. Macrophages produce a large variety of proinflammatory cytokines, chemokines, and eicosanoid metabolites in response to phagocytosis of Pneumocystis. Although these mediators participate in eradicating Pneumocystis, they also promote pulmonary injury (Limper et al., 1997).

Neutrophils alone are unable to control the infection. Unlike other opportunistic fungal infections, Pneumocystis disease is rare in patients with neutropenia. Neutrophils are associated with inflammation and, therefore, have been implicated in severity of disease. In fact, decreased pulmonary function and local lung inflammation and damage have been correlated with elevated neutrophil counts in HIV-infected patients with PCP (Kelly \& Shellito, 2010). The neutrophils recruited into the lungs release reactive oxidant species, proteases, and cationic proteins, which directly injure capillary endothelial cells and alveolar epithelial cells (Thomas \& Limper, 2004).

\subsection{Adaptive immunity (T cells and B cells)}

Both cellular and humoral immune systems are important in defence against Pneumocystis infection.

The activity of CD4+ T cells is pivotal in the host's defences against Pneumocystis, since most HIV-infected patients with PcP have CD4+ T-cell counts below 200 cells/mm ${ }^{3}$. CD4+ lymphocytes as memory cells coordinate and orchestrate the host inflammatory responses by means of the recruitment and activation of other immune effector cells, including monocytes and macrophages, which are responsible for elimination of the organism. Macrophage-derived TNF- $\alpha$ and interleukin-1 are believed to be necessary for initiating pulmonary responses to Pneumocystis infection that are mediated by CD4+ cells. The cells proliferate in response to Pneumocystis antigens and generate cytokine mediators, including lymphotactin and interferon gamma (IFN- $\gamma$ ). Lymphotactin, a chemokine, acts as a potent chemoattractant for further lymphocyte recruitment in PcP.

Although T lymphocytes are essential for the clearance of Pneumocystis, experimental data suggest that T-cell responses may also result in substantial pulmonary impairment during pneumonia. For instance, in severe combined immunodeficiency (SCID) mice infected with Pneumocystis, normal oxygenation and lung function occur despite active infection until the late stages of the disease. When the immune systems in these animals are reconstituted with 
the use of intact spleen cells, an intense T-cell-mediated inflammatory response ensues, resulting in substantially impaired gas exchange (Wright et al., 1999b). In the absence of brisk lung inflammation, Pneumocystis has little direct effect on pulmonary function. In a similar manner, in patients who have undergone bone marrow transplantation the clinical onset of $\mathrm{PcP}$ and of most marked alterations in lung function occur during engraftment (Thomas \& Limper, 2004).

The CD8+ T cells seem to play also an important role in control of Pneumocystis infection since in experimental animal models depletion of both CD4+ and CD8+ cells results in a more severe $\mathrm{PcP}$ than only depletion of $\mathrm{CD} 4+$ cells. However, their role may be less important than CD4+ T cells since CD8+ T-cell-depleted animals can still clear the infection (Lu \& Lee, 2008). Pneumocystis infection results in the marked accumulation of CD8+ T lymphocytes in the lung. Although not as extensively investigated as CD4+ T cells, insights into the role of CD8+ T cells in host defence against Pneumocystis have been achieved, but that is not nearly enough. Recent data provide the concept that CD8+ T cells, most likely those of the Tc1 phenotype, are critical for clearance of some fungal organisms including Pneumocystis, particularly in the context of CD4+ T-cell deficiency or dysfunction. CD8+ T cells have also been shown to play a detrimental role in Pneumocystis infection. CD8+ T cells are considered to be part of the damaging inflammatory response in CD4+ T-cell-depleted mice. The presence of CD8+ T cells affected surfactant function and it also has been shown to exacerbate TNF-a production (Steele et al., 2005).

Lastly, a significant role of humoral immune response in the host defence against Pneumocystis is supported by the observations that SCID animals require B cells to clear the infection (Burns et al., 1990), and that patients with agammaglobulinemia develop PcP despite of an intact cellular immune system (Alibrahim et al., 1998; Lu \& Lee, 2008). B lymphocytes appears to play an important role in the generation of CD4+ memory cells in response to Pneumocystis (Lu \& Lee, 2008).

\subsection{Cytokine and chemokine networks}

Various pro-inflammatory cytokines including IFN- $\gamma$, tumour necrosis factor alpha (TNF- $\alpha$ ), interleukin (IL)-8, IL-1 and IL-6 and chemokines such as RANTES (Regulated upon Activation normal T-cell Expressed, and Secreted), macrophage inflammatory protein (MIP)-1 $\alpha$, MIP-1 $\beta$ and MIP-2 release by macrophages, neutrophils, epithelial cells and lymphocytes are involved in the host immune response and lung damage during Pneumocystis disease (Calderon et al., 2007).

INF- $\gamma$ has a critical role for control lung inflammation during $\mathrm{PcP}$, although is not directly toxic to Pneumocystis organisms. This cytokine is produced primarily by CD4+ T cells. There is an indirect correlation between IFN-levels and severity of PcP (Kelly \& Shellito, 2010). IFN- $\gamma$ strongly activates the macrophage production of TNF- $\alpha$, superoxides, and reactive nitrogen species, each of which is implicated in the host defence against Pneumocystis (Wright et al., 1999a).

TNF-a is a potent pro-inflammatory cytokine secreted primarily by macrophage that promotes the recruitment of neutrophils, lymphocytes, and monocytes. Although their recruitment is important for clearance of the organisms, these cells injure the lung by releasing oxidants, cationic proteins, and proteases. TNF- $\mathrm{a}$ also induces the production of other cytokines and chemokines, including IL-8 and IFN- $\gamma$, which stimulate the recruitment and activation of inflammatory cells during Pneumocystis infection (Wright et al., 2004). The cell wall of Pneumocystis contains abundant beta-glucans, and studies have confirmed that the production of TNF-a by alveolar macrophages is mediated by recognition of the beta-glucan components of Pneumocystis. IL-8 is correlated with both 
neutrophil infiltration of the lung and impaired gas exchange during severe PcP (Thomas \& Limper, 2004).

The most important function of chemokines is to recruit effector cells to the site of injury. Many studies have found an increase in chemokine expression during PcP. In a SCID experimental model of PcP it has been found that expression levels of RANTES, MIP-1a, MIP-1 $\beta$ and MIP-2 were all upregulated after lymphocyte reconstitution of the SCID animal. In addition, the time course of chemokine expression correlates Pneumocystis clearance, but also with the lung inflammation (Wright et al., 1999a). Thus, the role of chemokines is essential for the resolution of infection, but overexpression may also result in a hyperinflammatory state and lung damage (Kelly \& Shellito, 2010).

\section{Clinical presentation and chest radiology}

In patients infected with $\mathrm{HIV}, \mathrm{PcP}$ is a common AIDS-defining illness and occurs most frequently in subjects with a CD4+ count less than 200 cells per $\mathrm{mm}^{3}$. The symptoms of PcP are nonspecific and $\mathrm{PcP}$ in patients with HIV infection tends to run a more subacute indolent course and tends to present much later, often after several weeks of symptoms, compared with $\mathrm{PcP}$ associated with other immunocompromising conditions. A more acute illness with symptoms including a cough productive with purulent sputum should suggest an alternate infectious diagnosis, such as bacterial pneumonia or tuberculosis

Patients with PcP often develop dyspnea (95\%), which increases over time; cough productive of clear sputum or non-productive cough; low grade or no fever; malaise, and sometimes chest tightness or pain. However, the clinical picture in individual patients is variable and many infectious and non-infectious processes can present identically. Also, the general hallmarks of this disease such as fever, shortness of breath, and diffuse infiltrates do not invariably occur, especially early in the course while the disease is mild (Thomas \& Limper, 2004). Acute dyspnea with pleuritic chest pain may indicate the development of a pneumothorax, which has been presented in $2 \%$ to $4 \%$ of patients (Sepkowitz et al., 1991). In all cases, a high index of suspicion and a thorough history are key factors in early detection of PcP. Physical examination may reveal tachypnea, tachycardia, and cyanosis. Lung auscultation usually reveals few abnormalities with dry cackles or rhonchi present in less than $50 \%$ of patients. Individuals with PcP can be hypoxemic with respiratory alkalosis but can also have normal alveolar-arterial gradients if identified early in the natural history of their disease. Elevated serum levels of lactate dehydrogenase (LDH) have been related with $\mathrm{PcP}$ and probably reflects lung parenchymal damage but is not specific and elevations can be seen in many pulmonary and non-pulmonary conditions. In general, laboratory abnormalities are less severe in HIV-infected patients than in non-HIV immunosuppressed patients (Hughes, 2004).

Classically, chest radiographic features of $\mathrm{PcP}$ are bilateral, symmetric, fine reticular interstitial infiltrates involving the perihilar areas (figure 1a), becoming more homogenous and diffuse as the severity of the infection increases (Thomas \& Limper, 2004). Less frequently, PcP may present with unilateral or asymmetrical opacities. Thin-walled cysts or pneumatocele are seen in $10-20 \%$ of cases. Pleural effusions and intrathoracic adenopathy are rare. Patients who receive aerosolized pentamidine have an increased frequency of upper-lobe infiltrates, pneumothorax, or cystic lesions. Early in the course of PcP, the chest radiograph may be normal in up to $25 \%$ of cases (Schliep \& Yarrish, 1999).

A high-resolution computed tomography scan is more sensitive than chest radiograph and is helpful when the chest radiography findings are equivocal. The typical appearance is patchy areas of ground-glass attenuation with a background of interlobular septal 
thickening or cystic lesions predominating in perihilar areas (figure 1b), even then chest radiographic findings are normal (Nyamande et al., 2007). While such findings are suggestive, they are not diagnostic. However, a negative high-resolution computed tomography scan may allow exclusion of PcP in patients with HIV.
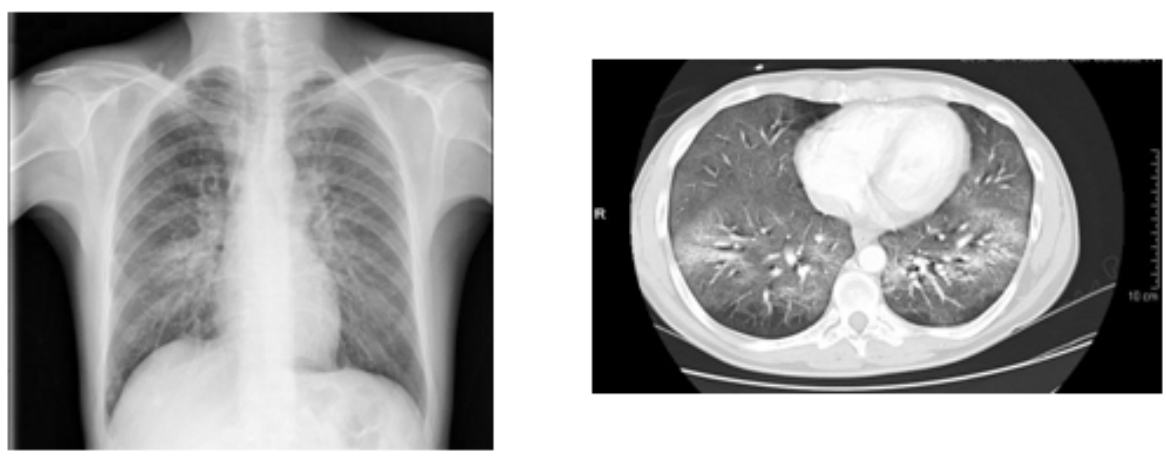

Fig. 1. Radiographic findings of Pneumocystis pneumonia in a patient with AIDS. (1a, left) Chest $x$-ray of a Pneumocystis pneumonia showing diffuse infiltrations in both lung fields. (1b, right) Chest high-resolution CT scan of a patient with AIDS revealing diffuse ground glass opacities and thickened alveolar septum in both lungs.

Extrapulmonary manifestations of $P$. jirovecii infection (extrapulmonary pneumocystosis) are distinctly unusual but they has been reported primarily among HIV-infected patients, particularly those who receive aerosolized pentamidine for prophylaxis of $\mathrm{PcP}$ and in those with advanced HIV infection who are not taking any prophylaxis. Mainly, during the terminal stage of HIV-related disease Pneumocystis organisms may disseminate from the lungs to other organs where they induce secondary visceral lesions. However, sometimes pulmonary infection may not be apparent when extrapulmonary lesions are detected. Lymph nodes, spleen, kidneys, liver, thyroid and bone marrow are the most commonly infected organs, but microorganisms have been also found in the brain, pancreas, skin, heart, muscle and other organs (Ng et al, 1997). For HIV-infected patients, extrapulmonary pneumocystosis limited to the choroid layer or ear (external auditory canal or middle ear) has a better prognosis, with good response to specific treatment, than disseminated pneumocystosis in multiple noncontiguous sites. Lesions are frequently nodular and may contain necrotic material or calcification. Extrapulmonary pneumocystosis in solid organs appears on computed tomography scan as focal, hypodense lesions with well-defined borders and central or peripheral calcification (Schliep \& Yarrish, 1999).

Immunorestitution disease (IRD) is defined as an acute symptomatic or paradoxical deterioration of a (most probably) preexisting infection that is temporally related to the recovery of the immune system and it is due to immunopathological damage associated with the reversal of immunosuppressive processes. PcP manifesting as a form of IRD has been described in both HIV and non-HIV immunosuppressed patients (Cheng et al., 2004; Jagannathan et al., 2009; Mori et al., 2009). Among HIV-infected patients, PcP manifesting acutely during the initiation of HAART is a well-recognized phenomenon (Wislez et al., 2001). AIDS-related PcP patients seem to be at risk of clinical deterioration due to IRD if antiretroviral therapy is started within one to two weeks after the initiation of treatment for $\mathrm{PcP}$ (Wislez et al., 2001). The onset of clinical deterioration is associated with an increase in the CD4+ lymphocyte count and a reduction in the HIV viral load (Wislez et al., 2001). 


\section{Prognosis}

Despite treatment, mortality of $\mathrm{PcP}$ still remains high. Several studies highlight that mortality rates are declining in patients with $\mathrm{PcP}$. However, in other studies, $\mathrm{PcP}$ has remained the leading cause of death among those nor receiving o failing to comply with HAART or PcP prophylaxis. Predictors of mortality include older age, recent injection drug use, increased total bilirrubin, low serum albumin, and alveolar-arterial oxygen gradient $>50 \mathrm{~mm} \mathrm{Hg}$ (Fei et al, 2009).

\section{Management PcP}

There is no universally agreed approach on to the initial management of patients with suspected PcP. Many institutions treat patients with suspected $\mathrm{PcP}$ empirically, while others pursue a definitive microbiological diagnosis (Huang, 2004). Since PcP can be rapidly progressive and the mortality rate remains high, early therapy is essential (Calderon et al, 2004; Roblot, 2005). Identification of patients having PcP into mild, moderate or severe disease allows to guide the choice of the drug for the treatment of PcP, as well as, to decide if adjuvant corticosteroids are indicated (table 1) (Miller et al., 1996). In AIDS-related PcP, the typical duration of therapy is at least 21 days because of the risk for relapse with shorter treatment duration. Patients generally improved after 4 to 8 days of therapy. Although the overall prognosis of patients whose degree of hypoxemia requires intensive care unit (ICU) admission or mechanical ventilation remains poor, survival in up to $50 \%$ of patients requiring ventilatory support has been reported. Patients with reasonable functional status and severe PcP should be offered ICU admission or mechanical ventilation (CDC, 2009).

\begin{tabular}{|l|l|l|l|}
\hline & Mild & Moderate & Severe \\
\hline Symptoms and signs & $\begin{array}{l}\text { Dyspnoea on exertion, } \\
\text { with or without cough } \\
\text { and sweats }\end{array}$ & $\begin{array}{l}\text { Dyspnoea on minimal } \\
\text { exertion and } \\
\text { occasionally at rest. } \\
\text { Cough and fever }\end{array}$ & $\begin{array}{l}\text { Dyspnoea and } \\
\text { tachypnoea at rest. } \\
\text { Persistent fever and } \\
\text { cough }\end{array}$ \\
\hline $\begin{array}{l}\text { Arterial oxygen tension } \\
\text { (PaO2) at rest }\end{array}$ & $>11.0 \mathrm{kPa}(82.7 \mathrm{mmHg})$ & $\begin{array}{l}8.0 \text { to } 11.0 \mathrm{kPa}(60-82.7 \\
\mathrm{mmHg})\end{array}$ & $<8.0 \mathrm{kPa}(60 \mathrm{mmHg})$ \\
\hline $\begin{array}{l}\text { Arterial oxygen } \\
\text { saturation (SaO2) at } \\
\text { rest }\end{array}$ & $>96 \%$ & 91 to $96 \%$ & $<91 \%$ \\
\hline Chest radiograph & $\begin{array}{l}\text { Normal, or minor } \\
\text { perihiliar shadowing }\end{array}$ & $\begin{array}{l}\text { Diffuse interstitial } \\
\text { shadowing }\end{array}$ & $\begin{array}{l}\text { Extension interstitial } \\
\text { shadowing with or } \\
\text { without diffuse alveolar } \\
\text { shadowing }\end{array}$ \\
\hline
\end{tabular}

Modified of Miller RF, et al., 1996.

Table 1. Grading of severity of Pneumocystis pneumonia.

\section{Diagnosis of PCP}

\subsection{Microscopic detection of Pneumocystis}

The single most important diagnostic tool for Pneumocystis infection is a high clinical suspicion. However, specific diagnosis of $\mathrm{PcP}$ requires documentation of the microorganism in respiratory specimens. Since Pneumocystis cannot be cultured, the diagnosis of PcP relies on microscopic detection of Pneumocystis organisms on stained respiratory specimens. Conventional stains such as toluidine blue O (TBO), Grocott's methenamine silver nitrate 
(GMS), or methanol Giemsa methods (figure 2) can be used to identify the organism (cysts or trophic forms) but immunofluorescent staining is the most common technique currently used. TBO or GMS stains facilitate rapid parasite detection, even at low magnification, in all kinds of clinical specimens. However, these dyes also stain the cell wall of yeasts or other fungi. For this reason, a good strategy to identify Pneumocystis organisms accurately in clinical specimens is to systematically associate the examination of both TBO- or GMS-stained smears and methanol-Giemsa-stained smears from the same specimen (table 2). Actually, methanol-Giemsa (or other equivalent panoptical Giemsa-like stains) makes it possible, on the one hand, to distinguish Pneumocystis organisms from other microorganism and, on the other hand, to identify the different Pneumocystis life-cycle stages. In fact, Giemsa and other stains with similar cytological affinities, such as Diff Quick or RAL-555, cause the parasite nuclei to stain pinkish purple and the cytoplasm to stain blue (Dei-Cas et al, 1998). They do not stain cystic or sporocytic walls, which appear like a clear peripheral halo around cystic forms. These polychrome stains make it possible accurately to distinguish Pneumocystis trophic or cystic forms from other fungi and also from host cells or cell debris. On the whole, the biggest advantage of methanol-Giemsa or Giemsa-like stain methods consists in staining trophic forms and sporocytes, which remain unidentified in TBO- or GMS-stained smears (Dei-Cas et al, 1998).

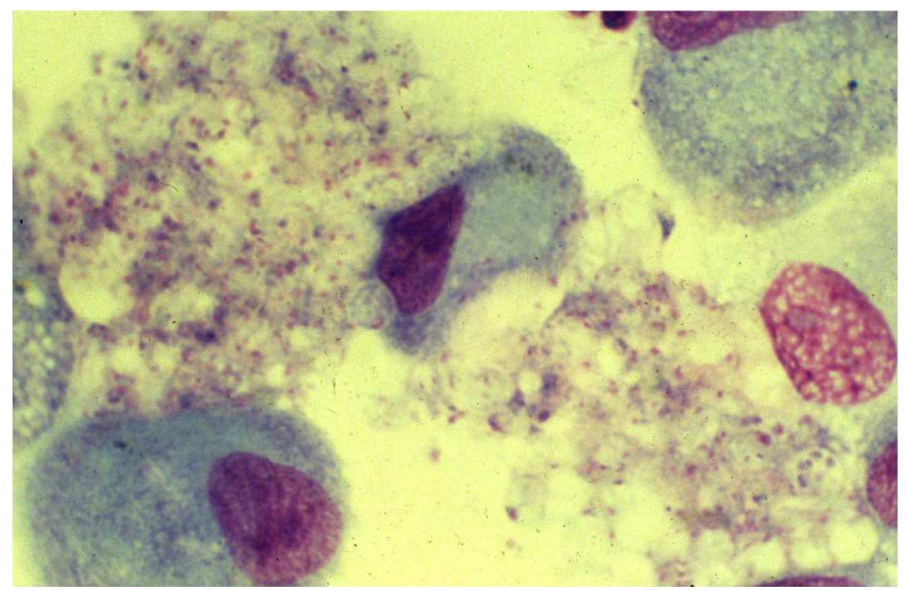

Fig. 2. Stain with methanol-Giemsa stain

Efficiency and cost-effectiveness of the different microscopic stains evoked here vary according to experience of groups, technical protocols, type and quality of the samples, local incidence of PcP, and the number of organisms present (Chouaid et al., 1995) (table 2). It is generally accepted, however, that association of methods that stain cystic cell wall (e.g. TBO or GMS) with panoptical techniques (methanol-Giemsa or analogous staining methods) is usually required (Dei-Cas et al., 2006). Moreover, it is usually recognized that specific antibody staining is mainly helpful to detect Pneumocystis organisms in non-BAL smears (e.g. induced sputum, expectorated sputum, gastric wash) and to clarify conflicting light microscopic observations (Aderaye et al., 2008; Cruciani et al., 2002; Kovacs et al., 1998; Limawongpranee et al., 2007).

Typically, the respiratory specimens are obtained by sputum induction or fiberoptic bronchoscopy with bronchoalveolar lavage (BAL). Sputum induction by inhalation of a 
hypertonic saline solution is the quickest and least-invasive method for definitively diagnosing PcP with a sensitivity between $50-90 \%$ and specificity of $99-100 \%$. Sputum induced may also be less sensitive in patients receiving aerosolized pentamidine for prophylaxis. All of the direct organism visualization methods can lead to false-negative results, consequently, a negative sputum induction cannot rule out a diagnosis of PcP. If sputum induction is nondiagnostic or cannot be performed, then bronchoscopy with BAL is the next step. A BAL that is negative for Pneumocystis rules out the diagnosis of PcP.

In order to detect Pneumocystis organisms in histological sections from lung or other organs, pathologists target usually the cystic forms, since trophic ones are uneasily identifiable in paraffin-embedded tissues. They use therefore GMS and, less frequently, TBO staining procedures adapted to tissue sections. Trophic forms can however be identified in eponembedded semi-thin sections stained with toluidine blue or other stains (Dei-Cas et al., 1998; Durand-Joly et al., 2000). Furthermore, Pneumocystis-specific fluorescein-, phosphatase or peroxidase-labeled monoclonal antibodies available from many suppliers may help to identify Pneumocystis organisms in BAL, induced sputum or tissue samples (table 2).

\begin{tabular}{|c|c|c|c|c|c|c|c|}
\hline Technique & $\begin{array}{l}\text { Suitable } \\
\text { kind of } \\
\text { sample }\end{array}$ & $\begin{array}{l}\text { Needed } \\
\text { experience }\end{array}$ & Sensitivity & Specificity & Advantages & Drawbacks & $\begin{array}{l}\text { Recommended } \\
\text { combination } \\
\text { with: }\end{array}$ \\
\hline \multicolumn{8}{|c|}{ Microscopy: } \\
\hline \multirow{3}{*}{$\begin{array}{l}\text { PC/IC } \\
\text { GMS/TBO }\end{array}$} & $\begin{array}{l}\text { BALF wet } \\
\text { smear }\end{array}$ & very good & variable & good & rapidity & $\begin{array}{l}\text { needs } \\
\text { confirmation by } \\
\text { other methods }\end{array}$ & $\begin{array}{l}\text { panoptical } \\
\text { stain }\end{array}$ \\
\hline & & & & & & & \\
\hline & $\begin{array}{l}\text { BALF air- } \\
\text { dried } \\
\text { cytospin } \\
\text { smear or } \\
\text { biopsy } \\
\text { (histological } \\
\text { section) } \\
\end{array}$ & average & high & average & cost; rapidity & $\begin{array}{l}\text { false positive (poor } \\
\text { experienced } \\
\text { staffs); identifies } \\
\text { only the cystic } \\
\text { stages }\end{array}$ & $\begin{array}{l}\text { panoptical } \\
\text { stain }\end{array}$ \\
\hline $\begin{array}{l}\text { Panoptical } \\
\text { stains* }\end{array}$ & $\begin{array}{l}\text { BALF air- } \\
\text { dried } \\
\text { cytospin } \\
\text { smear }\end{array}$ & \multicolumn{2}{|c|}{ very good average } & very high & $\begin{array}{l}\text { cost; rapidity; } \\
\text { identify all } \\
\text { Pneumocystis } \\
\text { stages }\end{array}$ & $\begin{array}{l}\text { limited sensitivity } \\
\text { (poor experienced } \\
\text { staffs) }\end{array}$ & GMS/TBO \\
\hline FL Mab & $\begin{array}{l}\text { BALF, IS or } \\
\text { sputum air- } \\
\text { dried } \\
\text { cytospin } \\
\text { smear } \\
\end{array}$ & good & high & good & $\begin{array}{l}\text { good } \\
\text { sensitivity/ } \\
\text { specificity }\end{array}$ & $\begin{array}{l}\text { cost; time- } \\
\text { consuming }\end{array}$ & - \\
\hline IP/AP Mab & $\begin{array}{l}\text { biopsy } \\
\text { (histological } \\
\text { section), air- } \\
\text { dried } \\
\text { cytospin } \\
\text { smear } \\
\end{array}$ & good & good & good & good specificity & $\begin{array}{l}\text { cost; time- } \\
\text { consuming }\end{array}$ & - \\
\hline PCR & $\begin{array}{l}\text { BALF, IS, } \\
\text { OW, NPA, } \\
\text { biopsy }\end{array}$ & average & very high & very high & $\begin{array}{l}\text { Helpful in HIV- } \\
\text { negative } \\
\text { patients; } \\
\text { rapidity (real- } \\
\text { time PCR } \\
\text { assays); non- } \\
\text { invasive }\end{array}$ & $\begin{array}{l}\text { cost; positive in } \\
\text { colonized patients }\end{array}$ & - \\
\hline
\end{tabular}




\begin{tabular}{|c|c|c|c|c|c|c|c|}
\hline Technique & $\begin{array}{l}\text { Suitable } \\
\text { kind of } \\
\text { sample }\end{array}$ & $\begin{array}{l}\text { Needed } \\
\text { experience }\end{array}$ & Sensitivity & Specificity & Advantages & Drawbacks & $\begin{array}{l}\text { Recommended } \\
\text { combination } \\
\text { with: }\end{array}$ \\
\hline & & & & & $\begin{array}{l}\text { sampling; } \\
\text { genotyping }\end{array}$ & & \\
\hline BG & serum & average & good & low & $\begin{array}{l}\text { rapidity; post- } \\
\text { therapeutic } \\
\text { control }\end{array}$ & $\begin{array}{l}\text { positive in other } \\
\text { deep fungal } \\
\text { infections }\end{array}$ & other tests \\
\hline KL-6 & serum & average & good & low & - & $\begin{array}{l}\text { positive in other } \\
\text { pulmonary } \\
\text { infections }\end{array}$ & \\
\hline $\begin{array}{l}\text { Serum } \\
\text { Pneumocystis } \\
\text { antibody } \\
\text { assay }\end{array}$ & serum & average & $\begin{array}{l}\text { depending } \\
\text { on antigen } \\
\text { and assay }\end{array}$ & $\begin{array}{l}\text { depending } \\
\text { on antigen } \\
\text { and assay }\end{array}$ & $\begin{array}{l}\text { helpful in } \\
\text { epidemiology } \\
\text { studies }\end{array}$ & $\begin{array}{l}\text { positive in people } \\
\text { without } \mathrm{PcP}\end{array}$ & other tests \\
\hline
\end{tabular}

*Giemsa or Giemsa-like stains. BALF: Bronchoalveolar lavage fluid; BG: serum beta-1,3-glucan; FL Mab: fluorescein-labeled Pneumocystis monoclonal antibody; GMS: Grocott-methenamine silver stain; IP/AP Mab: immuneperoxidase/alkaline-phosphatase labeled monoclonal antibody; IS: induced sputum; PC/IC: phase contrast/interference contrast; TBO: toluidine blue stain. KL-6: Mucin like glycoprotein.

Table 2. Laboratory diagnostic methods for Pneumocystis pneumonia.

\subsection{Molecular detection of Pneumocystis}

Many Pneumocystis PCR assays have been developed during the last two decades. PCR tool revealed highly efficacious to amplify Pneumocystis DNA from diverse kinds of clinical specimens (BALF, IS, expectorated sputum, oropharyngeal or nasopharyngeal wash samples, biopsy specimens) (figure 3) (de la Horra et al., 2006; Durand-Joly et al., 2005; Olsson et al., 1993; Wakefield et al., 1990). In the clinical laboratory, the use of molecular methods is mainly warranted to increase the sensitivity of $P$. jirovecii detection in clinical specimens in order to establish earlier PcP diagnosis, detecting low parasite rates, mainly in non-HIV infected patients with PcP, and detecting Pneumocystis DNA in noninvasive samples (Durand-Joly et al., 2005; Respaldiza et al., 2006) (table 2). Moreover, PCR assays followed by direct sequencing or other strategies were used for typing Pneumocystis isolates in order to identify parasite strains and to explore correlation between specific genotypes and virulence, transmissibility or drug susceptibility. PCR, especially nested PCR assays applied to noninvasive samples, have also been used to detect Pneumocystis colonization either in susceptible individuals or in apparently healthy people, including health care workers in hospitals (Durand-Joly et al., 2003; Medrano et al., 2005; Nevez et al., 2008).

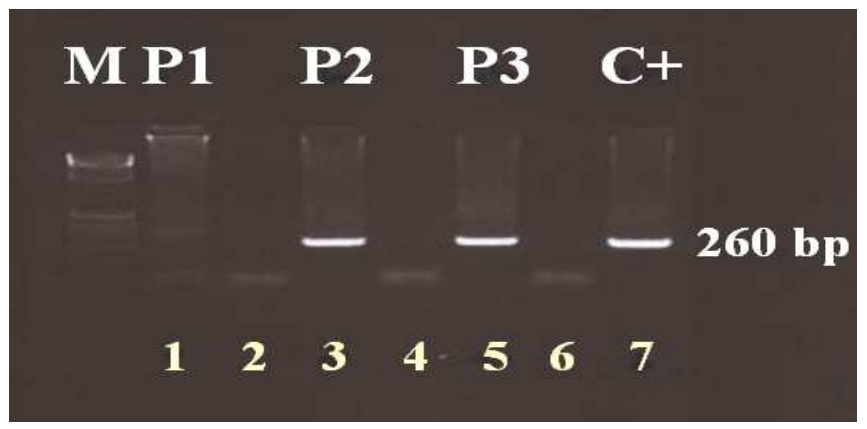

Fig. 3. Nested PCR (mtLSU rRNA region) results. 
M: molecular mass marker. Lane 1 (P1) negative specimen. Lanes 3 and 5 (P2, P3) positive specimens of oral wash in cystic fibrosis patients. Lane $7(\mathrm{C}+)$ positive control. Lanes 2,4 and 6 negative controls (water).

For PcP diagnosis in humans, conventional or real-time PCR assays based on the amplification of the large subunit of mitochondrial ribosomal DNA (mtLSUrDNA) (Wakefield et al., 1990) are the most commonly used, but many other sequences have been targeted (Major Surface Glycoprotein, Internal Transcribed Spacers, Thymidylate Synthase, Dihydrofolate Reductase, heat-shock protein 70, etc.) (Durand-Joly et al., 2005; Hugett et al., 2008). Comparative evaluating studies are uneasy to perform because of different clinical contexts, sampling methods, laboratory reagents or technical strategies used to DNA extraction, amplification or analysis of results (Durand-Joly et al., 2005).

In general, conventional or real-time Pneumocystis PCR assays have represented a significant advance in PcP laboratory diagnosis. Actually, highly sensitive and specific PCR tools, especially real-time PCR assays, improved the clinical diagnosis of PcP allowing an accurate, early diagnosis of Pneumocystis infection (Durand-Joly et al., 2005), which should lead to a decreased duration from onset of symptoms to treatment. This period has a recognized impact on prognosis since $\mathrm{PcP}$-associated respiratory failure requiring mechanic ventilation entails significant mortality (Huang, 2004). In addition, PCR assay may reveal $\mathrm{PcP}$ in patients with negative microscopic test. For instance, among 62 HIV-negative patients with clinical PcP diagnosed in the Lille University Hospital between 1998 and 2001, 30 patients $(48 \%)$ had positive PCR results with negative microscopic tests (Durand-Joly, 2002).

Notably, molecular techniques play a significant role when they are applied to noninvasive specimens as IS, oropharyngeal wash (OW, obtained by gargling $10 \mathrm{ml}$ of $0.9 \% \mathrm{NaCl}$ for $>60$ seconds) (Respaldiza et al., 2006) or nasopharyngeal aspirates (NPA) (Richards et al. 1994). When DNA sequences used as primers or probe have been adequately defined, the analytical specificity of Pneumocystis-PCR assays applied to noninvasive or to BALF samples should usually be of $100 \%$ (Durand-Joly et al., 2005). With regard to sensitivity, Pneumocystis-mtLSUrDNA PCR showed high analytical sensitivity for the detection of Pneumocystis organisms on BALF samples from AIDS patients, with a detection threshold of 0.5-1 organism $/ \mu \mathrm{l}^{-1}$ (Tamburrini et al., 1998). The sensitivity of PCR assays applied to OW (or other noninvasive samples) is certainly lower $(<80 \%)$ than that of PCR on BALF samples $(>95 \%$ ) (Tsolaki et al., 2008). However, OW can be easily repeated in order to monitor the evolution of infection and, potentially, the therapeutic response (Tsolaki et al., 2008).

A significant problem of Pneumocystis PCR assays is raised by Pneumocystis colonization (Calderon, 2009). Actually, a positive PCR result associated with a negative microscopic test may result from either Pneumocystis colonization or PcP. In common practice, this difficulty is often solved on the basis of a careful clinical, radiological and laboratory assessment of the patient pathological condition, as it is usually done to other infectious diseases, especially when their agents are opportunistic pathogens. However, the alternative of quantifying parasite rates was also explored (Larsen et al., 2002). Thus, a quantitative real-time PCR assay that targeted Pneumocystis Major Surface Glycoprotein (MSG) multigene family was applied to OW samples, and revealed significant differences between PcP patients and Pneumocystis colonized subjects in the number of MSG copies. The authors suggested a cutoff value of 50 MSG gene fragment copies/tube for distinguishing between the two conditions (Larsen et al., 2002). However, quantitative PCR results seemed difficult to use on the field. The main problem was inability to control the volume of the sample. Another 
difficulty is related with the kind of patients. Actually, it seems difficult to apply a same cutoff to AIDS patients, patients with other underlying diseases or individuals receiving chemoprophylaxis against Pneumocystis.

There is no formal agreement about an unequivocal definition of Pneumocystis colonization. The notion may however be characterized on the basis of clinical and experimental observations. In clinical practice, the diagnosis of Pneumocystis colonization or subclinical carriage is usually retained when Pneumocystis DNA is detected by PCR methods in respiratory samples from immunodepressed or immunocompetent subjects without symptoms or signs of Pneumocystis infection, and who do not progress to PcP (Morris et al., 2008) In these subjects, Pneumocystis organisms are only exceptionally detected by microscopy (Vidal et al., 2006). Interestingly, recent experimental data strengthened the biological significance of Pneumocystis colonization (Chabe et al., 2004). They demonstrated that Pneumocystis organisms can replicate in the lungs of immunocompetent carriers, stimulate an antibody response and be efficiently transmitted by airborne route to either naive immunocompetent hosts, who will develop a primary infection, or to immunosuppressed hosts, who may then develop PcP (Chabe et al., 2004). In addition, many evidences suggest that beyond $\mathrm{PcP}$, Pneumocystis colonization may induce local or systemic inflammation, a condition that could aggravate chronic pulmonary diseases. For instance, $P$. jirovecii pulmonary carriage in patients with chronic obstructive pulmonary disease (COPD) could favor the progression of this disease (Calderon et al., 2007; Morris et al., 2008).

Efforts have been made to associate specific $P$. jirovecii genotypes with virulence, drug susceptibility or other medically important biological properties of parasite strains. Some studies reported some correlation between polymorphism and clinical features (Miller \& Wakefield, 1999; Totet et al., 2003). Polymorphism of internal transcribed spacer (ITS1/ITS2) sequences was quite frequently used and more than 30 ITS1 genotypes and 40 ITS2 genotypes with more than 90 haplotypes (combinations of ITS1 and ITS2 types) have been reported (Beard, 2004).

Most polymorphism studies targeted mutations of the $P$. jirovecii dihydropteroate synthase (DHPS) gene, which could potentially be linked with sulfa resistance. Regarding this issue, and since effective $P$. jirovecii culture systems are unavailable, several groups have assessed putative trimethoprim-sulfamethoxazole (TMP-SMX) drug resistance by detecting Pneumocystis DHPS mutations. Indeed nonsynonymous DHPS point mutations at nucleotide positions 165 and 171 entail an amino acid change at positions 55 (Thr to Ala) and/or 57 (Pro to Ser) (Friaza et al., 2009). Such mutations confer resistance to sulfa drugs in other organisms, including Escherichia coli, Streptococcus pneumoniae and Plasmodium falciparum. The $P$. jirovecii DHPS mutant form has also been shown to be more resistant to sulfamethoxazole in a Saccharomyces cerevisiae model (Iliades et al., 2004), but it is still uncertain if Pneumocystis DHPS mutations lead to drug resistance in patients (Huang et al., 2000, 2004; Nahimana et al., 2004). Such mutations were shown to be associated with the use of TMP-SMX or dapsone (two DHPS inhibitors), the duration of sulfa or dapsone prophylaxis and with geographic areas in which sulfamethoxazole or dapsone were commonly used for PcP prophylaxis (Huang et al., 2004; Kazanjian et al., 2000). However, results of studies searching specifically to establish an association between the presence of $P$. jirovecii DHPS mutations and clinical outcomes, such as treatment failure or death, are contradictory (Alvarez-Martinez et al., 2008, Helweg-Larsen et al., 1999; Huang et al., 2004, 
Stein et al., 2004; van Hal et al., 2009). Outstandingly, most PcP patients carrying P. jirovecii isolates with DHPS mutations responded well to TMP-SMX treatment and survived probably because these mutations may confer a low-level of resistance to sulfa-drugs that is overcome by high drug concentration achieved in lung tissues by sulfamethoxazole (Calderon et al., 2004; Huang et al., 2004).

\subsection{Other laboratory diagnostic methods 7.3.1 Beta-D-glucan assay}

$\beta$-1,3-glucan (BG) is the main structural component of the cell wall of all fungi, including Pneumocystis cysts (Thomas \& Limper, 2007). Interestingly, high serum BG levels have been reported in patients with PcP (Desmet et al., 2009; Nakamura et al., 2009; Teramoto et al., 2000). Consistently, such levels decreased with effective anti-Pneumocystis treatment (Teramoto et al., 2000). Serum BG appeared therefore as a good marker of Pneumocystis infection. The potential utility of this assay was analyzed in a retrospective case-control study of patients with suspected PcP comparing BG with microscopic examination on BAL. The BG assay had a sensitivity of $92 \%$ and a specificity of $86 \%$ for detecting PcP for a ut-off level of $31.1 \mathrm{pg} / \mathrm{ml}$ (Tasaka et al., 2007). In a recent study, it has been observed that BG levels in HIV patients with PcP are higher than in non-HIV patients. This could be attributed to the fact that HIV patients have greater numbers of microorganisms that non-HIV patients (Nakamura et al., 2009).

However, BG levels could not be correlated with $\mathrm{PcP}$ prognosis, and false positive results could exceed more than $30 \%$ (Nakamura et al., 2009). False positive results were reported in patients undergoing bacterial septicemia, hemodialysis with cellulose dialysis membranes, treatment with immunoglobulin, glucan-containing antitumor drugs, amoxicillinclavulanate, piperacillin-tazobactam or contact with gauze or surgical sponges containing BG (Ponton, 2009). Furthermore, since invasive fungal infections induce also an increase of serum BG, the test should often be associated with laboratory assays aiming at detecting such infections (Desmet et al., 2009). These preliminary studies suggest that in the right clinical setting serum BG may provide a useful noninvasive diagnostic adjunct for patients with Pneumocystis infection. However, additional information is necessary to address the general specificity of $\mathrm{BG}$ in diagnosing $\mathrm{PcP}$ versus other fungal infections in diverse immune-suppressed patient populations and to differentiate among patients with $\mathrm{PcP}$ and patients with Pneumocystis colonization.

\subsubsection{KL-6}

KL-6 is a mucin-like glycoprotein expressed on type II pneumocytes and bronchiolar epithelial cells. This marker has reached elevated levels in several studies in patients with $\mathrm{PcP}$. However, the reported false-positive rate and level of detection were not as good as for the BG assay (Nakamura et al, 2009; Tasaka et al, 2007). Recent investigations indicate that KL-6 is more a generalized marker for alveolar epithelial injury (Sato et al, 2004) and high levels have also be found in non-fungal infections such as legionellosis, severe tuberculosis and respiratory syncythial virus bronchiolitis, and even in noninfectious interstitial lung disease (Inou et al., 1995; Kawasaki et al., 2009; Sukoh et al., 2001). Therefore, KL-6 elevation in $\mathrm{PcP}$ is thought to be related to lung damage and regeneration of epithelium lining and cannot be used as a specified marker of Pneumocystis infection. 


\subsubsection{S-adenosylmethionine (SAM)}

Some observations suggested that S-adenosylmethionine (SAM), which is a universal methyl donor synthesized from methionine and ATP by SAM synthetase, could stimulate Pneumocystis in vitro growth (Clarkson et al., 2004). Since SAM was depleted from both the culture medium and the plasma of rats with $\mathrm{PcP}$, it was hypothesized that Pneumocystis cells could scavenge SAM from host fluids due to the lack of SAM synthetase (Clarkson et al., 2004) Consistently, plasma SAM levels were found to be low in patients with PcP and to increase gradually with treatment (Skelly et al., 2003, 2008). These findings strengthened the idea of using plasma SAM levels as a non-invasive PcP diagnostic method. However, recent data showed that SAM-related issue could be more complex than previously thought. Firstly, differences in SAM levels between laboratories could be influenced by the method of measurement. Thus, Wang and colleagues using Chromatography Tandem Mass Spectrometry found generally higher plasma SAM levels than those reported before (Wang et al., 2008). The same group was unable to distinguish patients with acute PcP from the ones without PcP on the basis of plasma SAM levels, though these levels increased significantly with effective anti-Pneumocystis treatment. Indeed, the concern needs to be further explored because fasting status, dietary intake of methionine and other medications can affect plasma SAM concentration (Wang et al, 2008). Secondly, and contrarily to the results of previous works (Clarkson et al., 2004), P. carinii, P. murina and P. jirovecii have genes that encoded SAM synthetase (Sam1) (Kutty et al., 2008) . Moreover, the corresponding Sam 1 mRNA is transcribed, and the protein, which is enzymatically active, was immuno-localized in P. murina cells. Such data suggest strongly that Pneumocystis species do not depend on an exogenous source of SAM to survive (Kutty et al., 2008).

\subsubsection{Serological tests}

Serum antibody detection constitutes an adjunctive strategy currently used to diagnose systemic fungal infections, even in immunosupressed patients. This strategy was however only rarely used to $\mathrm{PCP}$ diagnosis because healthy subjects have frequently significant levels of serum anti-Pneumocystis antibody. Moreover, the antibody response against Pneumocystis infection is currently highly variable and the results reported by diverse groups are contradictory (Walzer, 2004). In contrast, Pneumocystis antibody assays, especially those using recombinant Pneumocystis antigens, constitutes an interesting tool in epidemiology (Daly et al., 2009).

\section{Treatment}

The recommended treatment of $\mathrm{PcP}$ has remained unchanged for many years, being Cotrimoxazole, an association of trimethoprim and sulfamethoxazole, the drug of choice as first line of treatment. Regarding which agent of second line must be choice preferably, data are limited (table 3). Drug related toxicities are increasing in HIV-infected patients and organ transplant recipients. Because of the potential for additive or synergistic toxicities associated with anti-Pneumocystis and antiretroviral therapies, certain health-care providers delay initiation of HAART until after the completion of anti-Pneumocystis therapy, or until at least 2 weeks after initiating anti-Pneumocystis therapy, despite some suggestion of potential benefit of early HAART in the treatment of patients with AIDS-related opportunistic infections (CDC, 2009; Zolopa et al., 2009). In order to a correct management of PcP is important to distinguish between progressive $\mathrm{PcP}$, drug toxicity and concomitant infection if clinical deterioration is detected. 


\section{Trimethoprim-sulfamethoxazole (TMP-SMX)}

TMP and SMX target sequential steps in the folate synthesis pathway. TMP inhibits dihydrofolate reductase and SMX inhibits dihydropteroate synthetase. TMP-SMX is the treatment of choice for $\mathrm{PcP}$ in all patients who tolerate this drug, and it achieves the most rapid clinical response of the anti-Pneumocystis agents (CDC, 2009; Helweg-Larsen et al., 2009). The recommended dose of TMP-SMX for adults (or children aged $>2$ months) is 15 to $20 \mathrm{mg} / \mathrm{kg} /$ day of TMP and 75 to $100 \mathrm{mg} / \mathrm{kg} /$ day of SMX intravenously every 6 or 8 hours. With renal dysfunction, dosing must be reduced. The bioavailability of TMP-SMX from oral therapy is comparable to parenteral administration (CDC, 2009; Mofenson et al., 2009).

Patients who have PcP despite the use of TMP-SMX prophylaxis, are usually successfully treated with TMP-SMX. In this way, the presence of mutations in the DHPS gene of $P$. jirovecii has been associated with resistance to sulfa drugs, although the clinical outcome is uncertain (Crothers et al. 2005; Huang et al., 2004; Stein et al., 2004). Drug related toxicities from TMP-SMX are greater than that from therapy with other anti-Pneumocystis agents. The side effects of TMP-SMX are: rash (30-55\%), (including Stevens-Johnson syndrome), fever (30-40\%), leukopenia (30-40\%), hepatitis (20\%), thrombocytopenia (15\%), azotemia (1-5\%), and hyperkaliemia (Eeftinck et al., 1990; Gordin et al., 1984; Hughes et al., 1995). Nephrotoxicity occurs frequently in the renal transplantation recipient receiving full-dose of TMP-SMX. Liver transplant recipients are particularly susceptible to TMP-SMX toxicity. Leucovorin to prevent myelosuppression is not recommended because its uncertain efficacy and a higher rate of failure (CDC, 2009).

\section{Pentamidine}

Pentamidine is an aromatic diamidine that has broad spectrum anti-protozoal activity. This drug inhibits metabolism of $P$ amino benzoic acid, interferes with anaerobic glycolysis, inhibits oxidative phosphorylation and impairs nucleic acid and protein synthesis. It was the first drug reported to treat $\mathrm{PcP}$ successfully and subsequent reports have confirmed the efficacy of intravenous pentamidine. Although intravenous pentamidine has been recommended as the main alternative to TMP-SMX for moderate to severe PcP (Gordin et al., 1984), a recent study has found a greater risk of death when pentamidine was used as first and second-line therapy for HIV-associated PcP with compared with TMP-SMX and clindamycin-primaquine (Helweg-Larsen et al., 2009). These findings could be due to toxicities related to pentamidine and the absence of an antibacterial effect, in contrast to TMP-SMX or clindamycin-primaquine, which might act against concomitant bacterial co-infection (Helweg-Larsen et al., 2009).

Pentamidine for children and adults is administered once a day at $4 \mathrm{mg} / \mathrm{kg}$ (maximum 300 mg daily) intravenously, infused slowly 1 to $2 \mathrm{hr}$ in $5 \%$ glucose; due to its toxicity the dose can be reduced to $3 \mathrm{mg} / \mathrm{kg}$. Aerosolized pentamidine should not be used because of limited efficacy and more frequent relapse, and intramuscular administration is not used due to the related complications (Conte et al., 1990). Side effects of pentamidine include azotemia, pancreatitis, hypo- or hyperglycemia, pancytopenia, electrolyte abnormalities, cardiac dysrhythmia and renal dysfunction (Conte et al., 1990). Pentamidine should be avoided in pancreas transplant recipients due to the potential for islet cell necrosis.

\section{Clindamycin-primaquine}

Clindamycin is a lincosamide antibiotic used to treat infections with anaerobic bacteria but can also be used to treat some protozoan diseases. Primaquine is an 8-aminoquinoline antiprotozoan agent. This combination is effective in adult patients with mild to moderate PcP, but 
data for children are not available (Toma et al., 1998). Clindamycin is given at 600 to $900 \mathrm{mg}$ intravenously or $300-450 \mathrm{mg}$ orally every 6 to 8 hours and primaquine is given orally at 15 to $30 \mathrm{mg} /$ day. Clindamycin component can be administered intravenously in severe cases; primaquine is only available orally. Recently, clindamycin-primaquine appeared superior to pentamidine as second-line therapy for $\mathrm{PcP}$ in patients failing or developing toxicity with TMP-SMX (Helweg-Larsen et al., 2009). Side effects of clindamycin include rash, anemia, neutropenia and the development of Clostridium difficile colitis. The main toxicity of primaquine is methemoglobinemia, thus, patients should be tested for glucose-6-phosphate dehydrogenase deficiency before administration of primaquine (Larsen, 2004).

\section{Dapsone}

Dapsone is a sulfone drug that inhibits DHPS and it is used as alternative therapeutic regimen for mild-to-moderate PcP. Dapsone must be taken with TMP (Medina et al., 1990). Although this association might have similar efficacy and fewer side effects than TMP-SMX, is less recommended due to the number of pills. The dosage of dapsone for adolescents and adults is $100 \mathrm{mg}$ orally once daily (among children aged $<13$ years, $2 \mathrm{mg} / \mathrm{kg} /$ day). The dosage of TMP for children and adults taken orally is $15 \mathrm{mg} / \mathrm{kg} /$ day divided into three doses (CDC, 2009; Mofenson et al., 2009). The most common adverse effects associated to dapsone are methemoglobinemia and hemolysis, especially in those with glucose-6phosphate dehydrogenase deficiency. Thus, patients should be tested for glucose-6phosphate dehydrogenase deficiency (Larsen et al. 2004).

\section{Atovaquone}

Atovaquone is a unique naphthoquinone that target the cytochome B complex and, thus, inhibits mitochondrial electron transport. This drug was developed clinically in the 1990s and it is available only as oral agent. It is used as second-line agent for treatment of mild to moderate PcP if TMP-SMX cannot be used. The standard dosing regimen for adults is atovaquone $750 \mathrm{mg}$ orally twice a day with food for increasing gastrointestinal absorption (30-40 mg/ kg/day for children < 3 months and $>24$ months of age; between 3-24 months of age, $45 \mathrm{mg} / \mathrm{kg} /$ day are required) (Medina et al., 1990; Mofenson et al., 2009). Mutations of the cytochrome $b$ gene have occurred in atovaquone-resistant isolates of Pneumocystis, but the clinical significance of gene mutations has not been determined (Kazanjian et al., 2001). The advantages of atovaquone include oral administration and fewer side effects. Disadvantages are its high cost and its bioavailability, although it has been improved with the micronized suspension formulation (Baggish \& Hill, 2002). The most frequently reported adverse effects are rash, nausea, diarrhea, elevation of liver enzyme levels and headache. Atovaquone does not cause bone marrow suppression (Larsen et al., 2004).

\section{Trimetrexate}

Trimetrexate is an analogue of methotrexate that is an inhibitor of dihydrofolate reductase, and in vitro it is 1500 times more potent than trimethoprim (Kovacs et al., 1988). This drug is effective for treating $\mathrm{PcP}$ but is available only in an intravenous formulation. Because this drug also inhibits human folate metabolism, leucovorin must be administered concomitantly to prevent cytopenias (Larsen et al., 2004). A clinical trial showed that trimetrexate is less effective but better tolerate than TMP-SMX against AIDS-related PcP (Sattler et al., 1994). Trimetrexate with folinic acid have been approved for use in patients with moderately severe $\mathrm{PcP}$, however, it is not longer available commercially. The dosage recommended for treatment of $\mathrm{PcP}$ is trimetrexate, $45 \mathrm{mg} / \mathrm{m}^{2}$ intravenously once daily, plus 
leucovorin $20 \mathrm{mg} / \mathrm{m}^{2}$ orally or intravenously four times daily (Sattler et al., 1994).. Leucovorin therapy must extend for 72 hours past the last dose of trimetrexate. For adults, trimetrexate may alternatively be dosed on a $\mathrm{mg} / \mathrm{kg}$ basis, depending on the patient's body weight: $<50 \mathrm{~kg}, 1.5 \mathrm{mg} / \mathrm{kg}$; $50-80 \mathrm{~kg}, 1.2 \mathrm{mg} / \mathrm{kg}$, and $>80 \mathrm{~kg}, 1.0 \mathrm{mg} / \mathrm{kg}$. Also, leucovorin may be dosed on a mg/ $\mathrm{kg}$ basis $(<50 \mathrm{~kg}, 0.6 \mathrm{mg} / \mathrm{kg}$, and $>50 \mathrm{~kg} 0.5 \mathrm{mg} / \mathrm{kg})$ administered every 6 hours. Despite the suggestion that leucovorin impairs the efficacy of TMP-SMX, there is no indication that the coadministration of leucovorin impairs the efficacy of trimetrexate for PcP (Larsen et al., 2004). In some cases trimetrexate plus leucovorin could be used as salvage treatment for PcP (Short et al., 2009).

\section{Adjunctive therapies}

The use of corticosteroids may reduce pulmonary inflammation response caused by the lysis of Pneumocystis in the lung after initiating treatment of PcP. Corticosteroids have been related with a significant benefit in terms of preventing deterioration in oxygenation in the first seven days of therapy, mortality, and reduction of intubations in AIDS patients (Briel et al., 2005). Corticosteroids are indicated in HIV-infected patients with a moderate-to-severe $\mathrm{PcP}$ who have hypoxemia (the partial pressure of arterial oxygen under $70 \mathrm{~mm} \mathrm{Hg}$ with the patient breathing room air or an alveolar-arteriolar gradient greater than 35). In these cases, corticosteroids should be administered as early as possible within 72 hours after starting anti-Pneumocystis therapy (Thomas \& Limper, 2004; CDC, 2009). Recommended dose are showed in table 3.

\begin{tabular}{|c|c|c|c|}
\hline & \multicolumn{3}{|c|}{ Moderate to severe Pneumocystis pneumonia } \\
\hline $\begin{array}{c}\text { Therapeutic } \\
\text { use }\end{array}$ & Drug & Dose & Route \\
\hline First line & $\begin{array}{l}\text { Trimethoprim- } \\
\text { Sulfamethoxazole }\end{array}$ & $\begin{array}{l}\text { 15-20 mg/Kg daily divided into } 3 \text { or } 4 \text { doses } \\
75-100 \mathrm{mg} / \mathrm{Kg} \text { daily divided into } 3 \text { or } 4 \text { doses }\end{array}$ & Intravenous \\
\hline Second line & $\begin{array}{l}\text { Primaquine plus } \\
\text { Clindamycin }\end{array}$ & $\begin{array}{l}30 \mathrm{mg} \text { daily } \\
600-900 \mathrm{mg} \text { three times daily }\end{array}$ & \begin{tabular}{|l|} 
Oral \\
Intravenous
\end{tabular} \\
\hline Second line & Pentamidine & $4 \mathrm{mg} / \mathrm{Kg}$ daily (3 mg/Kg if toxicities) & Intravenous \\
\hline $\begin{array}{l}\text { Salvage } \\
\text { therapy }\end{array}$ & $\begin{array}{l}\text { Trimetrexate plus } \\
\text { Leucovorin }\end{array}$ & $\begin{array}{l}45 \mathrm{mg} / \mathrm{m}^{2} \text { daily } \\
20 \mathrm{mg} / \mathrm{m}^{2} \text { four times daily }\end{array}$ & $\begin{array}{l}\text { Intravenous } \\
\text { Intravenous or } \\
\text { oral }\end{array}$ \\
\hline \multirow[t]{2}{*}{$\begin{array}{l}\text { Adjunctive } \\
\text { therapy }\end{array}$} & Methylprednisolone & $\begin{array}{l}\text { Days 1-5: } 80 \mathrm{mg} \text { daily divided into } 2 \text { doses } \\
\text { Days 6-10: } 40 \mathrm{mg} \text { daily } \\
\text { Days 11-21: } 20 \mathrm{mg} \text { daily } \\
\\
75 \% \text { of prednisone dose }\end{array}$ & Intravenous \\
\hline & \multicolumn{3}{|c|}{ Mild to moderate Pneumocystis pneumonia } \\
\hline First line & $\begin{array}{l}\text { Trimethoprim- } \\
\text { Sulfamethoxazole }\end{array}$ & $\begin{array}{l}\text { 15-20 mg/Kg daily divided into } 3 \text { doses } \\
75-100 \mathrm{mg} / \mathrm{Kg} \text { daily divided into } 3 \text { doses }\end{array}$ & Oral \\
\hline Second line & \begin{tabular}{|l|} 
Dapsone plus \\
Trimethoprim
\end{tabular} & $\begin{array}{l}100 \mathrm{mg} \text { daily } \\
15-20 \mathrm{mg} / \mathrm{Kg} \text { daily divided into } 3 \text { doses }\end{array}$ & $\begin{array}{l}\text { Oral } \\
\text { Oral or } \\
\text { intravenous }\end{array}$ \\
\hline Second line & $\begin{array}{l}\text { Primaquine plus } \\
\text { Clindamycin }\end{array}$ & $\begin{array}{l}\text { 15-30 mg daily } \\
300-450 \mathrm{mg} 3 \text { or } 4 \text { times daily }\end{array}$ & $\begin{array}{l}\text { Oral } \\
\text { Oral }\end{array}$ \\
\hline Second line & Atovaquone & $750 \mathrm{mg}$ two times daily & Oral with food \\
\hline
\end{tabular}

Table 3. Drugs therapy for treatment of Pneumocystis pneumonia in adults according to severity 


\section{Novel agents}

Novel agents undergoing clinical investigation include echinocandins and pneumocandins, which target synthesis of beta 1,3 glucan, a cell wall compound of Pneumocystis and other fungi.

Caspofungin is an echinocandin that acts on the cell wall by inhibiting $\beta$-1,3-glucan synthesis and it has been approved for several fungal infections as Candida and Aspergillus species. Caspofungin has shown activity against Pneumocystis in experimental animal models and it has strong activity on cyst forms and weak activity on trophic forms (Powles et al., 1998). Due to TMP-SMX affects only the trophic forms, it has been suggested that the association of TMP-SMX and caspofungin by fully inhibiting the organism life cycle, may provide a synergistic activity against Pneumocystis. According to this, it has been reported cases of PcP where the association of caspofungin and TMP-SMX achieved a complete cure of PcP (Utili et al., 2007). However, this promising therapeutic approach needs to be assessed by controlled clinical trials.

\section{Prevention}

Many studies have demonstrated that PcP can largely be prevented by administration of chemoprophylaxis to susceptible individuals (Di Cocco et al., 2009; Green et al., 2007; Podzamcser et al., 1995; Rodriguez \& Fishman, 2004) and according with the American Thoracic Society recommendations patients infected with HIV (Huang et al., 2006) need to receive prophylaxis to prevent disease depending on specific risks to the patient's system. Recommendations for chemoprophylaxis should be based on weighing the efficacy against the risk of adverse events, the risk of developments of antimicrobial resistance, and the cost of the intervention (Roblot et al., 2005). Medications recommended for chemoprophylaxis against $\mathrm{PcP}$ are listed in table 4.

\subsection{Primary prophylaxis}

The majority of recommendations are based in studies performed in HIV-infected patients. Guidelines recommend starting primary prophylaxis against PcP in HIV-infected adolescents and adults, including pregnant and patients under HAART, when the CD4 cell count is less than 200 cells $/ \mathrm{mm}^{3}$ or the patient has a history of oropharyngeal candidiasis. Patients with a CD4 cell percentage of $<14 \%$ or a history of an AIDS-defining illness should be considered for chemoprophylaxis (CDC, 2009). Prophylaxis recommendations for HIVinfected children are age-based. Chemoprophylaxis should be provided for children 6 years or older based on adults guidelines, for children aged 1 to 5 years if CD4 counts are less than 500 cells $/ \mathrm{mm}^{3}$ or CD4 percentage is less than $15 \%$, and for all HIV-infected infants younger than 12 months (Zolopa et al., 2009).

TMP-SMX is the recommended prophylactic agent in both primary and secondary prophylaxis for PCP, because of its high efficacy, relative safety, low cost, and broad antimicrobial spectrum (CDC, 2009; Di Cocco et al., 2009; Roblot et al., 2005; Rodriguez \& Fishman, 2004). TMP-SMX also is effective in preventing Toxoplasma gondi, Isospora belli, Cyclospora cayetanensis and some bacterial infections such us, Streptococcus pneumoniae, Salmonella, Haemophilus, Staphylococcus, common gram-negative gastrointestinal and urinary pathogens (Rodriguez \& Fishman, 2004). Either one single-strength tablet daily or one double-strength tablet daily are the preferred regimens, but the first regimen might be better 
tolerated than the second (CDC, 2009). An alternative choice can be one double-strength tablet three times per week (CDC, 2009; Roblot et al., 2005). TMP-SMX at a dose of one double-strength tablet daily confers cross-protection against toxoplasmosis and selected common respiratory bacterial infections. Lower doses of TMP-SMX also likely confer such protection (CDC, 2009; Di Cocco et al., 2009).

For patients who have an adverse reaction that is not life threatening, prophylaxis with TMP-SMX should be reinstituted. These patients might better tolerate reintroduction of the drug with a gradual increase in dose or reintroduction of TMP-SMX at a reduced dose or frequency (CDC, 2009). If TMP-SMX is not tolerated, a second choice would be dapsone given $100 \mathrm{mg}$ daily, dapsone $50 \mathrm{mg}$ daily plus pyrimethamine $50 \mathrm{mg}$ weekly plus leucovorin $25 \mathrm{mg}$ weekly or dapsone 200 plus pyrimethamine $75 \mathrm{mg}$ plus leucovorin $25 \mathrm{mg}$ weekly, aerosolized pentamidine $300 \mathrm{mg}$ monthly administered by an ultrasonic or jet-nebulizer, and atovaquone $1500 \mathrm{mg}$ daily $(\mathrm{CDC}, 2009)$. Dapsone is effective and inexpensive but

\begin{tabular}{|c|c|c|c|c|}
\hline Drug & Dose for adults & Dose for children & Route & Comments \\
\hline $\begin{array}{l}\text { Trimethoprim- } \\
\text { Sulfamethoxazole }\end{array}$ & $\begin{array}{l}160 / 800 \mathrm{mg} \text { (DS tablet) } \\
\text { per day or } 3 \text { times per } \\
\text { week } \\
80 / 400 \mathrm{mg} \text { (SS tablet) } \\
\text { per day }\end{array}$ & $\begin{array}{l}150 / 750 \mathrm{mg} / \mathrm{m}^{2} \text { body } \\
\text { surface area (max: } \\
320 / 1600 \mathrm{mg} \text { ) as single } \\
\text { or } 2 \text { divided doses } 3 \\
\text { times per week }\end{array}$ & Oral & $\begin{array}{l}\text { First choice } \\
\text { Weekly regimen is } \\
\text { recommended if daily } \\
\text { therapy in not tolerated }\end{array}$ \\
\hline Dapsone & $100 \mathrm{mg}$ per day & $\begin{array}{l}2 \mathrm{mg} / \mathrm{Kg} \text { body weight } \\
(\mathrm{max}: 100 \mathrm{~g}) \text { per day } \\
4 \mathrm{mg} / \mathrm{Kg} \text { body weight } \\
(\mathrm{max}: 200 \mathrm{~g}) \text { per week }\end{array}$ & Oral & $\begin{array}{l}\text { Alternative choice } \\
\text { Ensure patient does not } \\
\text { have Glucose-6 } \\
\text { phosphate } \\
\text { dehydrogenase } \\
\text { deficiency }\end{array}$ \\
\hline Pentamidine & $300 \mathrm{mg}$ per month & $\begin{array}{l}300 \mathrm{mg} \text { per month } \\
\text { (aged } \geq 5 \text { years) }\end{array}$ & Aerosol & Alternative choice \\
\hline Atovaquone & $1500 \mathrm{mg}$ per day & $\begin{array}{l}30-45 \mathrm{mg} / \mathrm{Kg} \text { body } \\
\text { weight according to age } \\
\text { per day }\end{array}$ & Oral & $\begin{array}{l}\text { Alternative choice } \\
\text { Take with high-fat } \\
\text { meals for maximal } \\
\text { absorption }\end{array}$ \\
\hline $\begin{array}{l}\text { Dapsona }+ \\
\text { Pyrimethamine }+ \\
\text { Leucovorin }\end{array}$ & $\begin{array}{l}50 \mathrm{mg} \text { per day } \\
50 \mathrm{mg} \text { per week } \\
25 \mathrm{mg} \text { per week }\end{array}$ & & $\begin{array}{l}\text { Oral } \\
\text { Oral } \\
\text { Oral }\end{array}$ & $\begin{array}{l}\text { Alternative choice } \\
\text { Ensure patient does not } \\
\text { have Glucose-6 } \\
\text { phosphate } \\
\text { dehydrogenase } \\
\text { deficiency } \\
\text { Effective in preventing } \\
\text { toxoplasmosis }\end{array}$ \\
\hline $\begin{array}{l}\text { Dapsona }+ \\
\text { Pyrimethamine }+ \\
\text { Leucovorin }\end{array}$ & $\begin{array}{l}200 \mathrm{mg} \text { per week } \\
75 \mathrm{mg} \text { per week } \\
25 \mathrm{mg} \text { per week }\end{array}$ & & $\begin{array}{l}\text { Oral } \\
\text { Oral } \\
\text { Oral }\end{array}$ & $\begin{array}{l}\text { Alternative choice } \\
\text { Ensure patient does not } \\
\text { have Glucose-6 } \\
\text { phosphate } \\
\text { dehydrogenase } \\
\text { deficiency } \\
\text { Effective in preventing } \\
\text { toxoplasmosis }\end{array}$ \\
\hline
\end{tabular}

Table 4. Prophylaxis regimens for Pneumocystis pneumonia. 
associated with more serious adverse effects than atovaquone (El-Sadr et al., 1998). Atovaquone is effective, safe and it is effective against Toxoplasma gondii but it is more expensive (Rodriguez \& Fishman, 2004). The widespread concept that TMP-SMX is contraindicated for prophylaxis in patients treated with methotrexate might be obsolete because the safety of one single-strength tablet daily or one double-strength tablet thriceweekly has been proved in clinical studies (Langford et al., 2003). However, these patients need to receive folate supplementation besides blood counts and liver-function tests should be closely monitored (Roblot, 2005).

Primary prophylaxis should be discontinued for HIV-infected adult and adolescent patients who have responded to HAART with an increase in CD4 counts major than 200 cells $/ \mathrm{mm}^{3}$ during more than 3 months (Lopez Bernaldo et al., 2001). Prophylaxis should be reintroduced if the CD4 cell count decreases to less than 200 cells $/ \mathrm{mm}^{3}$.

\subsection{Secondary prophylaxis}

HIV-infected adults and adolescents patients who have developed previous episodes of PcP should receive secondary prophylaxis (Thomas \& Limper, 2004). Chemoprophylaxis should be discontinued for adult and adolescent patients when CD4 cell count increases to more than 200 cells $/ \mathrm{mm}^{3}$ for a period of 3 months as a result of HAART (Lopez Bernaldo et al., 2001). Prophylaxis should be reintroduced if the CD4 count decreases again to less than 200 cells $/ \mathrm{mm}^{3}$. If $\mathrm{PcP}$ recurs at a CD4 count higher than 200 cells $/ \mathrm{mm}^{3}$, continuing PcP prophylaxis for life would be prudent (CDC, 2009).

\section{Conclusions}

Pneumocystis jirovecii is an atypical fungus that causes PcP mainly in HIV-infected individuals. Today, $\mathrm{PcP}$ is still a major cause of morbidity and mortality among AIDS patients, and constitutes a worldwide problem to public health. While the incidence of PcP among HIV infected individuals has decreased in developed countries, the prevalence of AIDS-related PcP in developing countries remains high and poorly controlled. The epidemiology of this infection is only beginning to be understood. The accumulating evidence suggests that $P$. jirovecii is a highly infectious organism with low virulence that takes advantage of hosts as temporary reservoirs of infection. In this sense, colonization with $P$. jirovecii (that is infection without disease) has recently gained attention as a important issue for understanding the complete cycle of human Pneumocystis infection. The clinical presentation in HIV-infected patients may differ from that in other immunosuppressed patients and its diagnosis continues to be challenging. Clinicians must be familiar with its presentation and management because mild cases are sometimes difficult to diagnose. The emergence of highly sensitive and specific molecular methods for $\mathrm{PcP}$ diagnosis have represented a significant advance in order to establish earlier PcP diagnosis, detect low parasite rates, and detect Pneumocystis DNA in non-invasive samples. Co-trimoxazole is the most effective medication for its prevention and treatment but other alternative medications are also available. Future clinical research should include studying the transmission and epidemiology of $\mathrm{PcP}$ in populations worldwide, improving the diagnosis of $\mathrm{PcP}$, improving regimens for prophylaxis and treatment in various patient populations, and determining the significance of the DHPS mutations in various populations and in different geographic locations. Furthermore, the threat of emerging 
resistance to available anti-Pneumocystis drugs highlights the need to continue investigating the biology of this organism in the hope of developing novel treatment strategies.

\section{References}

Aderaye G, Woldeamanuel Y, Asrat D, et al. (2008). Evaluation of Toluidine Blue O staining for the diagnosis of Pneumocystis jiroveci in expectorated sputum sample and bronchoalveolar lavage from HIV-infected patients in a tertiary care referral center in Ethiopia. Infection, Vol. 36, pp. 237-243, ISSN 0300-8126

Alvarez-Martínez MJ, Moreno A, Miró JM et al. (2008). Pneumocystis jirovecii pneumonia in Spanish HIV-infected patients in the combined antiretroviral therapy era: prevalence of dihydropteroate synthase mutations and prognostic factors of mortality. Diagn Microbiol Infect Dis, Vol. 62, pp. 34-43, ISSN 0732-8893

Alibrahim, A., Lepore, M., Lierl, M. et al. (1998). Pneumocystis carinii pneumonia in an infant with X-linked agammaglobulinemia. J Allergy Clin Immunol, Vol.101, pp. 552-553, ISSN 0091-6749

Aliouat-Denis CM, Chabé M, Demanche C, Aliouat el M, Viscogliosi E, Guillot J, et al. (2008). Pneumocystis species, co-evolution and pathogenic power. Infect Genet Evol, Vol. 8, pp. 708-26, ISSN 1567-1348

Baggish AL, Hill DR. (2002). Antiparasitic agent atovaquone. Antimicrob Agents Chemother, Vol. 46, pp. 1163-1173. ISSN 0066-4804

Beard CB. (2004). Molecular typing and epidemiological insights. In: Pneumocystis carinii Pneumonia (3rd edition). Walzer PD, Cushion MT (eds.), Marcel Dekker, Inc., New York, 479-504. ISBN 0-8247-5451-4

Benfield, TL., Prento, P., Junge, J. et al. (1997). Alveolar damage in AIDS-related Pneumocystis carinii pneumonia. Chest, Vol.111, No.5, (May 1997), pp. 1193-1199, ISSN 0012-3692

Briel M, Boscacci R, Furrer H, Bucher HC. (2005). Adjunctive corticosteroids for Pneumocystis jiroveci pneumonia in patients with HIV infection: a meta-analysis of randomised controlled trials. BMC Infect Dis, Vol. 5, pp. 101. ISSN 1471-2334

Burns, SM., Read, JA., Yap, PL. et al. (1990). Reduced concentrations of IgG antibodies to Pneumocystis carinii in HIV infected patients during active Pneumocystis carinii infection and the possibility of passive immunisation. J Infect, Vol.20, pp. 33-39. ISSN 0163-4453

Calderon E, de la Horra C, Montes-Cano MA, Respaldiza N, Martín-Juan J, Varela JM. (2004). Resistencia genotípica a sulfamidas en pacientes con neumonía por Pneumocystis jiroveci. Med. Clin. (Barc), Vol. 122, pp. 617-619, ISSN 0025-7753

Calderon EJ, Rivero L, Respaldiza N et al. (2007). Systemic inflammation in patients with chronic obstructive pulmonary disease who are colonized with Pneumocystis jirovecii. Clin Infect Dis, Vol. 45, pp. 17-19, ISSN 1058-4838

Calderon EJ. (2009). Epidemiology of Pneumocystis infection in human. J Mycol Med, Vol. 19, pp. 270-275, ISSN 1156-5233

Calderon EJ. (2010a). Pneumocystis infection: seeing beyond the tip of the iceberg. Clin Infect Dis, Vol. 50, pp. 354-356, ISSN 1058-4838

Calderon EJ, Gutiérrez-Rivero S, Durand-Joly I, Dei-Cas E. (2010b). Pneumocystis infection in humans: diagnosis and treatment. Expert Rev Anti Infect Ther, Vol. 8, pp. 683-701, ISSN 1478-7210 
Centers for Disease Control and Prevention. (2009). Guidelines for Prevention and Treatment of Opportunistic Infections in HIV-Infected Adults and Adolescents. MMWR, Vol. 58, pp. 1-216, ISSN 0149-2195

Chabé M, Dei-Cas E, Creusy C et al. (2004). Immunocompetent hosts as a reservoir of Pneumocystis organisms: histological and RT-PCR data demonstrate active replication. Eur J Clin Microbiol Infect Dis, Vol. 23, pp. 89-97, ISSN 0934-9723

Cheng VC, Hung IF, Wu AK, Tang BS, Chu CM, \& Yuen KY. (2004). Lymphocyte surge as a marker for immunorestitution disease due to Pneumocystis jiroveci pneumonia in HIV-negative immunosuppressed hosts. Eur J Clin Microbiol Infect Dis, Vol. 23, pp. 512-514, ISSN 1058-4838

Chouaid C, Housset B, Lebeau B. (1995). Cost-analysis of four diagnostic strategies for Pneumocystis carinii pneumonia in HIV-infected subjects. Eur Respir J, Vol. 8, pp. 1554-1558, ISSN 0903-1936

Clarkson AB, Merali S. (2004). Polyamines, Iron, and Pneumocystis carinii. In: Pneumocystis carinii Pneumonia (3rd edition), Walzer PD, Cushion MT (eds.), Marcel Dekker, Inc., New York, 577-605. ISBN: 0-8247-5451-4

Coleman, DL., Doder, PM., Goleen, JA. et al. (1984). Correlation between serial pulmonary function test and fiberoptic bronchoscopy in patients with Pneumocystis carinii pneumonia and the acquired immune deficiency syndrome. Am Rev Respir Dis, Vol.129, pp. 491-493, ISSN 0003-0805

Conte JE, Jr., Chernoff D, Feigal DW, Jr., et al. (1990). Intravenous or inhaled pentamidine for treating Pneumocystis carinii pneumonia in AIDS: a randomized trial. Ann Intern Med, Vol. 113, pp. 203-209, ISSN 0003-4819

Crothers K, Beard CB, Turner J, et al. (2005). Severity and outcome of HIV-associated Pneumocystis pneumonia containing Pneumocystis jirovecii dihydropteroate synthase gene mutations. AIDS, Vol. 19, pp. 801-805, ISSN 0269-9370

Daly K, Koch J, Respaldiza N et al. (2009). Geographical variation in serological responses to recombinant Pneumocystis jirovecii major surface glycoprotein antigens. Clin Microbiol Infect, Vol. 15, pp. 937-942, ISSN 1469-0691

de Boer MG, Bruijnesteijn van Coppenraet LE, Gaasbeek A, et al. (2007). An outbreak of Pneumocystis jiroveci pneumonia with 1 predominant genotype among renal transplant recipients: interhuman transmission or a common environmental source? Clin Infect Dis, Vol. 44, pp. 1143-9, ISSN 1058-4838

Dei-Cas E, Fleurisse L, Aliouat EM et al. (1998). Morphological and ultrastructural methods for Pneumocystis. FEMS Immunol. Med Microbiol, Vol. 22, pp. 185-189, ISSN 09288244

Dei-Cas E. (2000). Pneumocystis infections: the iceberg?. Med Mycol, Vol. 38, pp. 23-32, ISSN 1369-3786

Dei-Cas E, Chabé M, Moukhlis R et al. (2006). Pneumocystis oryctolagi sp. nov., an uncultured fungus causing pneumonia in rabbits at weaning: review of current knowledge, and description of a new taxon on genotypic, phylogenetic and phenotypic bases. FEMS Microbiol. Rev, Vol. 30, pp. 853-871, ISSN 0168-6445

de la Horra C, Varela JM, Friaza V, et al. (2006). Comparison of single and touchdown PCR protocols for detecting Pneumocystis jirovecii DNA in paraffin-embedded lung tissue samples. J. Eukaryot. Microbiol, Vol. 53, (Suppl 1), pp. 98-99, ISSN 1066-5234 
Desmet S, Van Wijngaerden E, Maertens J et al. (2009). Serum (1-3)-beta-D-glucan as a tool for diagnosis of Pneumocystis jirovecii pneumonia in patients with human immunodeficiency virus infection or hematological malignancy. J Clin Microbiol, Vol. 47, pp. 3871-3874, ISSN 0095-1137

Di Cocco P, Orlando G, Bonanni L, et al. (2009). A systematic review of two different trimetoprim-sulfamethoxazole regimens used to prevent Pneumocystis jirovecii and no prophylaxis at all in transplant recipients: appraising the evidence. Transplant Proc, Vol. 41, pp. 1201-1203, ISSN 0041-1345

Durand-Joly I, Wakefield AE, Palmer RJ et al. (2000). Ultrastructural and molecular characterization of Pneumocystis carinii isolated from a rhesus monkey (Macaca mulatta). Med Mycol, Vol. 38, pp. 61-72, ISSN 1369-3786

Durand-Joly I. (2002). Épidémiologie moléculaire de la pneumocystose humaine. Caractérisation génétique et phénotypique de Pneumocystis jirovecii et espèces proches. Thesis Dissertation. Lille, France.

Durand-Joly, I., Soula, F., Chabe, M et al. (2003). Longterm colonization with Pneumocystis jirovecii in hospital staffs: a challenge to prevent nosocomial pneumocystosis. $J$ Eukaryot Microbiol, Vol. 50 (Suppl.), pp. 614-615,ISSN 1066-5234

Durand-Joly I, Chabé M, Soula F, Delhaes L, Camus D, Dei-Cas E. (2005). Molecular diagnosis of Pneumocystis pneumonia (PcP). FEMS Immunol. Med Microbiol, Vol. 45, pp. 405-410, ISSN 0928-8244

Edman JC, Kovacs JA, Masur H, Santi DV, Elwood HJ, Sogin ML. (1988). Ribosomal RNA sequence shows Pneumocystis carinii to be a member of the fungi. Nature, Vol. 334, pp. 519-22, ISSN 0028-0836

Eeftinck Schattenkerk JK, Lange JM, van Steenwijk RP, Danner SA. (1990). Can the course of high dose cotrimoxazole for Pneumocystis carinii pneumonia in AIDS be shorter? A possible solution to the problem of cotrimoxazole toxicity. J Intern Med, Vol. 227, pp. 359-362, ISSN 1365-2796

Fei MW, Kim EJ, Sant CA, et al. (2009). Predicting mortality from HIV-associated Pneumocystis pneumonia at illness presentation: an observational cohort study. Thorax, Vol. 64, pp. 1070-1076, ISSN 0028-4793

Friaza V, Montes-Cano MA, Respaldiza N, Morilla R, Calderón EJ, de la Horra C. (2009). Prevalence of dihydropteroate synthase mutations in Spanish patients with HIVassociated Pneumocystis pneumonia. Diagn Microbiol Infect Dis, Vol. 64, pp. 104-105, ISSN 0732-8893

Gordin FM, Simon GL, Wofsy CB, Mills J. (1984). Adverse reactions to trimethoprimsulfamethoxazole in patients with the acquired immunodeficiency syndrome. Ann Intern Med, Vol. 100, pp.495-499, ISSN 0003-4819

Green H, Paul M, Vidal L, Leibovici L. (2007). Prophylaxis of Pneumocystis pneumonia in immunocompromised non-HIV-infected patients: systematic review and metaanalysis of randomized controlled trials. Mayo Clin Proc, Vol. 82, pp. 1052-1059, ISSN 0025-6196

Helweg-Larsen J, Benfield TL, Eugen-Olsen J, Lundgren JD, Lundgren B. (1999). Effects of mutations in Pneumocystis carinii dihydropteroate synthase gene on outcome of AIDS-associated P. carinii pneumonia. Lancet, Vol. 354, pp. 1347-1351, ISSN 01406736 
Helweg-Larsen J, Benfield T, Atzori C, Miller RF. (2009). Clinical efficacy of first- and second-line treatments for HIV-associated Pneumocystis jirovecii pneumonia: a tricentre cohort study. J Antimicrob Chemother, Vol. 64, pp. 1282-1290, ISSN 0305-7453

Huang L, Beard CB, Creasman J et al. (2000). Sulfa or sulfone prophylaxis and geographic region predict mutations in the Pneumocystis carinii dihydropteroate synthase gene. J Infect Dis, Vol. 182, pp. 1192-1198, ISSN 0022-1899

Huang L. (2004). Clinical presentation and diagnosis of Pneumocystis pneumonia in HIVinfected patients. In: Pneumocystis carinii Pneumonia, $3^{\text {rd }}$ edition, Walzer PD, Cushion MT (eds.), Marcel Dekker, Inc., New York, 349-406. ISBN 0-8247-5451-4

Huang L, Crothers K, Atzori C et al. (2004). Dihydropteroate synthase gene mutations in Pneumocystis and sulfa resistance. Emerg Infect Dis, Vol. 10, pp. 1721-1728, ISSN 1080-6059

Huang L, Morris A, Limper AH, Beck JM; ATS Pneumocystis Workshop Participants. (2006). An Official ATS Workshop Summary: Recent advances and future directions in Pneumocystis pneumonia (PCP). Proc Am Thorac Soc, Vol. 3, pp. 655-664, ISSN 15463222

Huggett JF, Taylor MS, Kocjan G et al. (2008). Development and evaluation of a real-time PCR assay for detection of Pneumocystis jirovecii DNA in bronchoalveolar lavage fluid of HIV-infected patients. Thorax, Vol. 63, pp. 154-159, ISSN 0028-4793

Hughes WT, LaFon SW, Scott JD, Masur H. (1995). Adverse events associาated with trimethoprim-sulfamethoxazole and atovaquone during the treatment of AIDSrelated Pneumocystis carinii pneumonia. J Infect Dis, Vol. 171, pp. 1295-1301, ISSN 0022-1899

Hughes WT. (2004). Pneumocystis Pneumonitis in Non-HIV-Infected Patients: Update. In: Pneumocystis carinii Pneumonia (3rd edition). Walzer PD, Cushion MT (eds.), Marcel Dekker, Inc., New York, 407-434, ISBN 0-8247-5451-4

Iliades P, Meshnick SR, Macreadie IG. (2004). Dihydropteroate synthase mutations in Pneumocystis jiroveci can affect sulfamethoxazole resistance in a Saccharomyces cerevisiae model. Antimicrob Agents Chemother, Vol. 48, pp. 2617-2623, ISSN 00664804

Inoue Y, Nishimura K, Shiode M, et al. (1995). Evaluation of serum KL-6 levels in patients with pulmonary tuberculosis. Tuber Lung Dis, Vol. 76, pp. 230-233, ISSN 0962-8479

Jagannathan P, Davis E, Jacobson M, \& Huang L. (2009). Life-threatening immune reconstitution inflammatory syndrome after Pneumocystis pneumonia: a cautionary case series. AIDS, Vol. 23, pp. 1794-1796, ISSN 0269-9370

Kawasaki Y, Aoyagi Y, Abe Y, et al. (2009). Serum KL-6 levels as a biomarker of lung injury in respiratory syncytial virus bronchiolitis. J Med Virol, Vol. 81, pp. 2104-2108, ISSN 0146-6615

Kazanjian P, Armstrong W, Hossler PA et al. (2000). Pneumocystis carinii mutations are associated with duration of sulfa or sulfone prophylaxis exposure in AIDS patients. J Infect Dis, Vol. 182, pp. 551-557, ISSN 0022-1899

Kazanjian P, Armstrong W, Hossler P.A, et al. (2001). Pneumocystis carinii cytochrome b mutations are associated with atovaquone exposure in patients with AIDS. J Infect Dis, Vol. 183, pp. 819-822, ISSN 0022-1899

Kelly, MN. \& Shellito, JE. (2010). Current understanding of Pneumocystis immunology. Future Microbiol, Vol.5, pp. 43-65, ISSN 1746-0913 
Kovacs JA, Ng VL, Masur H et al. (1988). Diagnosis of Pneumocystis carinii pneumonia: improved detection in sputum with use of monoclonal antibodies. $N$ Engl J Med, Vol. 318, pp. 589-593, ISSN 0028-4793

Krajicek. BJ., Limper, AH., \& Thomas, CF. (2008). Advances in the biology, pathogenesis and identification of Pneumocystis pneumonia. Curr Opin Pulm Med. 2008; Vol. 14, pp. 228-234, ISSN 1070-5287

Krajicek, BJ., Thomas, CFJr. \& Limper, AH. (2009). Pneumocystis pneumonia: current concepts in pathogenesis, diagnosis, and treatment. Clin Chest Med, Vol.30; pp. 265278, ISSN 0272-5231

Kutty G, Hernandez-Novoa B, Czapiga M, Kovacs JA. (2008). Pneumocystis encodes a functional S-adenosylmethionine synthetase gene. Eukaryot Cell, Vol. 7, pp. 258-267, ISSN 1535-9786

Langford CA, Talar-Williams C, Barron KS, Sneller MC. (2003). Use of cyclophosphamideinduction methotrexate-maintenance regimen for the treatment of Wegener's granulomatosis: extended follow-up and rate of relapse. Am J Med, Vol. 114, pp. 463-469,ISSN 0002-9343

Larsen HH, Masur H, Kovacs JA et al. (2002). Development and evaluation of a quantitative, touchdown, real-time PCR assay for diagnosing Pneumocystis carinii pneumonia. J Clin Microbiol, Vol. 40, pp. 490-494, ISSN 0095-1137

Larsen HH, Masur H, Kovacs JA. (2004). Current regimens for treatment and prophylaxis of Pneumocystis jiroveci pneumonia. In: Pneumocystis carinii Pneumonia, $3^{\text {rd }}$ edition, Walzer PD, Cushion MT (eds.), Marcel Dekker, Inc., New York, 505-538, ISBN 08247-5451-4

Limper, AH., Hoyte, JS. \& Standing, JE.. (1997). The role of alveolar macrophages in Pneumocystis carinii degradation and clearance from the lung. J Clin Invest, Vol.99, pp. 2110-2107, ISSN 0021-9738

Lopez Bernaldo de Quiros JC, Miro JM, Peña JM, et al. (2001). A randomized trial of the discontinuation of primary and secondary prophylaxis against Pneumocystis carinii pneumonia after highly active antiretroviral therapy in patients with HIV infection. N Engl J Med, Vol. 344, pp. 159-167, ISSN 0028-4793

Lu, JJ. \& Lee CH. (2008). Pneumocystis pneumonia. J Formos Med Assoc, Vol.107, pp. 830-842, ISSN 0929-6646

Medina I, Mills J, Leoung G, et al. (1990). Oral therapy for Pneumocystis carinii pneumonia in the acquired immunodeficiency syndrome: a controlled trial of trimethoprimsulfamethoxazole versus trimethoprim-dapsone. N. Engl. J. Med, Vol. 323, pp. 776782, ISSN 0028-4793

Medrano FJ, Montes-Cano M, Conde M, et al. (2005). Pneumocystis jirovecii in general population. Emerg Infect Dis, Vol. 11, pp. 245-250, ISSN 1080-6059

Miller RF, Le Noury J, Corbett EL, Felton JM, De Cock KM. (1996). Pneumocystis carinii infection: current treatment and prevention. J Antimicrob Chemother. Vol. 37, Suppl B, pp. 33-53, ISSN 0305-7453

Miller RF, Wakefield AE. (1999). Pneumocystis carinii genotypes and severity of pneumonia. Lancet, Vol. 353, pp. 2039-2040, ISSN 0140-6736

Miller RF, Ambrose HE, Wakefield AE. (2001). Pneumocystis carinii f. sp. hominis DNA in immunocompetent health care workers in contact with patients with $P$. carinii pneumonia. J Clin Microbiol, Vol. 39, pp. 3877-3882, ISSN 0095-1137 
Mofenson LM, Brady MT, Danner SP, et al. (2009). Guidelines for the Prevention and Treatment of Opportunistic Infections among HIV-exposed and HIV-infected children: recommendations from CDC, the National Institutes of Health, the HIV Medicine Association of the Infectious Diseases Society of America, the Pediatric Infectious Diseases Society, and the American Academy of Pediatrics. MMWR Recomm Rep, Vol. 58 (RR-11), pp. 1-166, ISSN 1057-5987

Montes-Cano MA, Chabe M, Fontillon-Alberdi M, de La Horra C, Respaldiza N, Medrano FJ, et al. (2009). Vertical transmission of Pneumocystis jirovecii in humans. Emerg Infect Dis, Vol. 15, pp. 125-127, ISSN 1080-6059

Mori S, Polatino S, \& Estrada-Y-Martin RM. (2009). Pneumocystis-associated organizing pneumonia as a manifestation of immune reconstitution inflammatory syndrome in an HIV-infected individual with a normal CD4+ T-cell count following antiretroviral therapy. Int J STD AIDS; Vol. 20. pp. 662-665, ISSN 0956-4624

Morris A, Beard CB, Huang L. (2002). Update on the epidemiology and transmission of Pneumocystis carinii. Microbes Infect, Vol. 4, pp. 95-103, ISSN 1286-4579

Morris A, Wei K, Afshar K, Huang L. (2008). Epidemiology and clinical significance of Pneumocystis colonization. J Infect Dis, Vol. 97, pp. 10-17, ISSN 0022-1899

Nahimana A, Rabodonirina M, Bille J, Francioli P, Hauser PM. (2004). Mutations of Pneumocystis jirovecii dihydrofolate reductase associated with failure of prophylaxis. Antimicrob Agents Chemother, Vol. 48, pp. 4301-4305, ISSN 0066-4804

Nakamura H, Tateyama M, Tasato D et al. (2009). Clinical utility of serum beta-D-glucan and KL-6 levels in Pneumocystis jirovecii pneumonia. Intern Med, Vol. 48, pp. 195-202, ISSN 1349-7235

Nevez G, Chabé M, Rabodonirina M et al. (2008). Nosocomial Pneumocystis jirovecii infections. Parasite, Vol. 15, pp. 359-365, ISSN 1776-1042

Ng VL, Yajko DM, Hadley WK. (1997). Extrapulmonary pneumocystosis. Clin Microbiol Rev, Vol. 10, pp. 401-418, ISSN 0893-8512

Nyamande, K., Lalloo, UG., \& Vawda, F. (2007). Comparison of plain chest radiography and high-resolution $\mathrm{CT}$ in human immunodeficiency virus infected patients with community-acquired pneumonia: a sub-Saharan Africa study. Br J Radiol, 2007; Vol. 80, pp. 302-306, ISSN 0007-1285

Olsson M, Elvin K, Löfdahl S, Linder E. (1993). Detection of Pneumocystis carinii DNA in sputum and bronchoalveolar lavage samples by polymerase chain reaction. J Clin Microbiol, Vol. 31, pp. 221-226, ISSN 0095-1137

Olsson M, Eriksson BM, Elvin K, Strandberg M, Wahlgren M. (2001). Genotypes of clustered cases of Pneumocystis carinii pneumonia. Scand J Infect Dis, Vol. 33, pp. 285-289, ISSN 0036-5548

Podzamczer D, Salazar A, Jimenez J, et al. (1995). Intermittent trimethoprimsulfamethoxazole compared with dapsone-pyrimethamine for the simultaneous primary prophylaxis of Pneumocystis pneumonia and toxoplasmosis in patients infected with HIV. Ann Intern Med, Vol. 122, pp. 755-761, ISSN 0003-4819

Pontón J. (2009). Utilidad de los marcadores biológicos en el diagnóstico de la candidiasis invasora. Rev Iberoam Micol, Vol. 26, pp. 8-14, ISSN 1130-1406

Powles MA, Liberator P, Anderson J, et al. (1998). Efficacy of MK-991 (L- 743,872), a semisynthetic Pneumocandin, in murine models of Pneumocystis carinii. Antimicrob Agents Chemother, Vol. 42, pp. 1985-1989, ISSN 0066-4804 
Prevost, MC., Escamilla, R., Aliouat, EM., et al. (1998) Pneumocystosis pathophysiology. FEMS Immunol Med Microbiol, Vol. 28, pp. 123-128, ISSN 0928-8244

Richards CG, Wakefield AE, Mitchell CD. (1994). Detection of Pneumocystis DNA in nasopharyngeal aspirates of leukaemic infants with pneumonia. Arch Dis Child, Vol. 71, pp. 254-255, ISSN 1743-0585

Sato H, Callister ME, Mumby S, et al. (2004). KL-6 levels are elevated in plasma from patients with acute respiratory distress syndrome. Eur Respir J, Vol. 23, pp. 142-145, ISSN 0903-1936

Schliep, TC., Yarrish, RL. (1999). Pneumocystis carinii pneumonia. Semin Respir Infect, 1999; Vol. 14, pp. 333-343, ISSN 0882-0546

Sepkowitz., KA., Telzak, EE., \& Gold, JW, et al. (1991). Pneumothorax in AIDS. Ann Intern Med, 1991; Vol. 114, pp. 455-459, ISSN 0003-4819

Short CE, Gilleece YC, Fisher MJ, Churchill DR. (2009). Trimetrexate and folinic acid: a valuable salvage option for Pneumocystis jirovecii pneumonia. AIDS, Vol. 23, pp. 1287-1290, ISSN 0269-9370

Sukoh N, Yamamoto H, Kikuchi E, et al. (2001). A case of severe Legionella pneumonia monitored with serum SP-A, SP-D, and KL-6. Nihon Kokyuki Gakkai Zasshi, Vol. 39, pp. 126-130, ISSN 0301-1542

Rabodonirina M, Vanhems P, Couray-Targe S, et al. (2004). Molecular evidence of interhuman transmission of Pneumocystis pneumonia among renal transplant recipients hospitalized with $\mathrm{HIV}$-infected patients. Emerg Infect Dis, Vol. 10, pp. 1766-1773, ISSN 1080-6059

Respaldiza N, Medrano FJ, Medrano AC, Varela JM, de la Horra C, Montes-Cano M, et al. (2004). High seroprevalence of Pneumocystis infection in Spanish children. Clin Microbiol Infect, Vol. 10, pp. 1029-1031, ISSN 1198-743X

Respaldiza N, Montes-Cano MA, Friaza V, et al. (2006). Usefulness of oropharyngeal washings for identifying Pneumocystis jirovecii carriers. J Eukaryot Microbiol, Vol. 53, (Suppl 1), pp. 100-101, ISSN 1066-5234

Rivero L, de la Horra C, Montes-Cano MA, Rodríguez-Herrera A, Respaldiza N, Friaza V, et al. (2008). Pneumocystis jirovecii transmission from immunocompetent carriers to infant. Emerg Infect Dis, Vol. 14, pp. 1116-1118, ISSN 1080-6059

Roblot, F. (2005). Management of Pneumocystis pneumonia in patients with inflammatory disorders. Expert Rev Anti Infect. Ther, Vol. 3, pp. 435-444, ISSN 1478-7210

Rodriguez, M., Fishman, JA. (2004). Prevention of infection due to Pneumocystis spp. in human immunodeficiency virus-negative immunocompromised patients. Clin Microbiol Rev, 2004; Vol. 17, pp. 770-82, ISSN1098-6618

Sattler FR, Frame P, Davis R, et al. (1994). Trimetrexate with leucovorin versus trimethoprim-sulfamethoxazole for moderate to severe episodes of Pneumocystis carinii pneumonia in patients with AIDS: a prospective, controlled multicenter investigation of the AIDS Clinical Trials Group Protocol 029/031. J Infect Dis, Vol. 170, pp. 165-172, ISSN 0022-1899

Skelly M, Hoffman J, Fabbri M, Holzman RS, Clarkson AB Jr, Merali S. (2003). Sadenosylmethionine concentrations in diagnosis of Pneumocystis carinii pneumonia. Lancet, Vol. 361, pp. 1267-1268, ISSN 0140-6736. 
Skelly MJ, Holzman RS, Merali S. (2008). S-adenosylmethionine levels in the diagnosis of Pneumocystis carinii pneumonia in patients with HIV infection. Clin Infect Dis, Vol. 46, pp. 467-471, ISSN 1058-4838

Stein CR, Poole C, Kazanjian P, Meshnick SR. (2004). Sulfa use, Dihydropteroate sythase mutations, and Pneumocystis jirovecii pneumonia. Emerg Infect Dis, Vol. 10, pp. 17601765, ISSN 1080-6059

Steele, C., Shellito, JE. \& Kolls, JK. (2005). Immunity against the opportunistic fungal pathogen Pneumocystis. Medical Mycology, Vol. 43; pp. 1-19, ISSN 1369-3786

Stringer SL, Stringer JR, Blase MA, Walzer PD, Cushion MT. (1989). Pneumocystis carinii: sequence from ribosomal RNA implies a close relationship with fungi. Exp Parasitol, Vol. 68, pp. 450-456, ISSN 0014-4894

Tamburrini E, Mencarini P, Visconti E, et al. (1998). Potential impact of Pneumocystis genetic diversity on the molecular detection of the parasite in human hosts. FEMS Immunol Med Microbiol, Vol. 22, pp. 37-49, ISSN 0928-8244

Tasaka S, Hasegawa N, Kobayashi S, et al. (2007). Serum indicators for the diagnosis of pneumocystis pneumonia. Chest, Vol. 131, pp. 1173-1180, ISSN 0012-3692

Teramoto S, Sawaki D, Okada S, Ouchi Y. (2000). Markedly increased plasma (1-->3)-beta-Dglucan is a diagnostic and therapeutic indicator of Pneumocystis carinii pneumonia in a non-AIDS patient. J Med Microbiol, Vol. 49, pp. 393-394, ISSN 0022-2615

Thomas, CF., Limper, AH. (2004). Pneumocystis pneumonia. N Engl J Med,. 2004; Vol. 350, pp :2487-2498. ISSN 0028-4793

Thomas CF Jr, Limper AH. (2007). Current insights into the biology and pathogenesis of Pneumocystis pneumonia. Nat Rev Microbiol, Vol. 5, pp. 298-308, ISSN 1740-1526

Toma E, Thorne A, Singer J, et al. (1998). Clindamycin with primaquine vs. Trimethoprimsulfamethoxazole therapy for mild and moderately severe Pneumocystis carinii pneumonia in patients with AIDS: a multicenter, double-blind, randomized trial. Clin Infect Dis, Vol. 27, pp. 524-30, ISSN 1058-4838

Totet A, Pautard JC, Raccurt C, Roux P, Nevez G. (2003). Genotypes at the internal transcribed spacers of the nuclear rRNA operon of Pneumocystis jirovecii in nonimmunosuppressed infants without severe pneumonia. J Clin Microbiol, Vol. 41, pp. 1173-1180, ISSN 0095-1137

Tsolaki AG, Miller RF, Wakefield AE. (1999). Oropharyngeal samples for genotyping and monitoring response to treatment in AIDS patients with Pneumocystis carinii pneumonia. J. Med. Microbiol, Vol. 48, pp. 897-905, ISSN 0022-2615

van Hal SJ, Gilgado F, Doyle T et al. (2009). Clinical significance and phylogenetic relationship of novel Australian Pneumocystis jirovecii genotypes. J Clin Microbiol, Vol. 47; pp. 1818-1823, ISSN 0095-1137

Vassallo, R., Kottom, TJ., Standing, JE. et al. (2001). Vitronectin and fibronectin function as glucan binding proteins augmenting macrophage responses to Pneumocystis carinii. Am J Respir Cell Mol Biol, Vol.25, pp. 203-211, ISSN1044-1549

Vidal S, de la Horra C, Martín J, et al. (2006). Pneumocystis jirovecii colonisation in patients with interstitial lung disease. Clin Microbiol Infect, Vol. 12, pp. 231-235, ISSN 10584838

Utili R, Durante-Mangoni E, Basilico C, Mattei A, Ragone E, Grossi P. (2007). Efficacy of caspofungin addition to trimethoprim-sulfamethoxazole treatment for severe 
Pneumocystis pneumonia in solid organ transplant recipients. Transplantation, Vol. 84, pp. 685-688, ISSN 0041-1345

Vargas SL, Ponce CA, Gigliotti F, et al. (2000). Transmission of Pneumocystis carinii DNA from a patient with $P$. carinii pneumonia to immunocompetent contact health care workers. J Clin Microbiol, Vol. 38, pp. 1536-1538, ISSN 0095-1137

Wakefield AE, Pixley FJ, Banerji S et al. (1990). Detection of Pneumocystis carinii with DNA amplification. Lancet, Vol. 336, pp. 451-453, ISSN 0140-6736

Wakefield AE. (1996). DNA sequences identical to Pneumocystis carinii f. sp. carinii and Pneumocystis carinii f. sp. hominis in samples of air spora. J Clin Microbiol, Vol. 34, pp. 1754-1759, ISSN 0095-1137

Walzer, PD. (1993). Pneumocystis carinii: recent advances in basic biology and their clinical application. AIDS, Vol.7, pp. 1293-1305, ISSN 0269-9370

Walzer PD. (2004). Immunological Features of Pneumocystis Infection in Humans. In: Pneumocystis carinii Pneumonia, $3^{\text {rd }}$ edition, Walzer PD, Cushion MT (eds.), Marcel Dekker, Inc., New York, 451-477, ISBN 0-8247-5451-4

Wang P, Huang L, Davis JL et al. (2008). A hydrophilic-interaction chromatography tandem mass spectrometry method for quantitation of serum s-adenosylmethionine in patients infected with human immunodeficiency virus. Clin Chim Acta, Vol. 396, pp. 86-88, ISSN 0009-8981

Wazir, JF., Ansari, NA. (2004). Pneumocystis carinii infection. Update and review. Arch Pathol Lab Med, 2004; Vol. 128, pp. 1023-1027, ISSN 0003-9985

Wislez M, Bergot E, Antoine M, et al. (2001). Acute respiratory failure following HAART introduction in patients treated for Pneumocystis carinii pneumonia. Am J Respir Crit Care Med, Vol. 164, pp. 847-851, ISSN 1073-449X

Wright, TW., Gigliotti, F., Finkelstein, JN., et al. (1999). Immune-mediated inflammation directly impairs pulmonary function, contributing to the pathogenesis of Pneumocystis carinii pneumonia. J Clin Invest, Vol.104, pp. 1307-1317, ISSN 00219738

Wright, TW., Johnston, CJ., Harmsen, AG. et al. (1999). Chemokine gene expression during Pneumocystis carinii-driven pulmonary inflammation. Infect Immun, Vol.67, pp. 3452-3460, ISSN 0019-9567

Wright, TW., Notter, RH., Wang, Z., et al. (2001). Pulmonary inflammation disrupts surfactant function during Pneumocystis carinii pneumonia. Infect Immun, Vol.69, pp. 758-764, ISSN 0019-9567

Wright, TW., Pryhuber, GS., Chess, PR., et al. (2004). TNF receptor signalling contributes to chemokine secretion, inflammation, and respiratory deficits during Pneumocystis pneumonia. J Immunol, Vol.172, pp. 2511-2521, ISSN 0022-1767

Wu AK, Cheng VC, Tang BS, et al. (2004). The unmasking of Pneumocystis jiroveci pneumonia during reversal of immunosuppression: case reports and literature review. BMC Infect Dis, Vol.4, pp.57, ISSN 1471-2334

Zolopa A, Andersen J, Powderly W, et al. (2009). Early antiretroviral therapy reduces AIDS progression/death in individuals with acute opportunistic infections: a multicenter randomized strategy trial. PLoS One, Vol. 4, pp. e5575, ISSN 1932-6203 


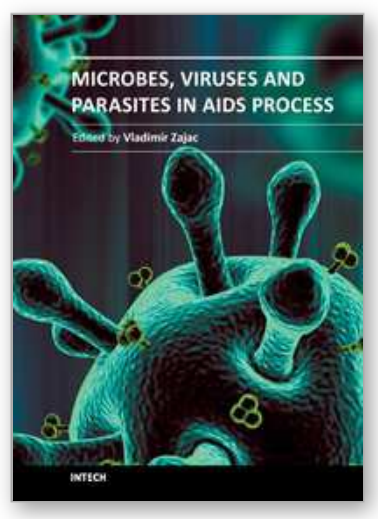

\author{
Microbes, Viruses and Parasites in AIDS Process \\ Edited by Prof. VladimÃr Zajac
}

ISBN 978-953-307-601-0

Hard cover, 390 pages

Publisher InTech

Published online 19, October, 2011

Published in print edition October, 2011

The main goal in compiling this book was to highlight the situation in Africa in terms of AIDS and opportunistic diseases.Â Several chapters reveal great poverty, an apocalyptic situation in many parts of Africa.Â Global migration of people resulted in their exposure to pathogens from all over the world. This fact has to be acknowledged and accepted as African reality. New, unconventional hypotheses, not determined by established dogmas, have been incorporated into the book, although they have not yet been sufficiently validated experimentally.Â It still applies that any dogma in any area of science, and medicine in particular, has and always will hinder progress. According to some biologists, in the future, AIDS is very likely to occur in a number of variations, as a direct result of the ongoing processes in the global human society. Thus, we urgently need a comprehensive solution for AIDS, in order to be ready to fight other, much more dangerous intruders.

\title{
How to reference
}

In order to correctly reference this scholarly work, feel free to copy and paste the following:

Jose M. Varela, Francisco J. Medrano, Eduardo Dei-Cas and Enrique J. Calderón (2011). Pneumocystis jirovecii Pneumonia in AIDS Patients, Microbes, Viruses and Parasites in AIDS Process, Prof. VladimÃr Zajac (Ed.), ISBN: 978-953-307-601-0, InTech, Available from: http://www.intechopen.com/books/microbes-virusesand-parasites-in-aids-process/pneumocystis-jirovecii-pneumonia-in-aids-patients

\section{INTECH}

open science | open minds

\author{
InTech Europe \\ University Campus STeP Ri \\ Slavka Krautzeka 83/A \\ 51000 Rijeka, Croatia \\ Phone: +385 (51) 770447 \\ Fax: +385 (51) 686166 \\ www.intechopen.com
}

\author{
InTech China \\ Unit 405, Office Block, Hotel Equatorial Shanghai \\ No.65, Yan An Road (West), Shanghai, 200040, China \\ 中国上海市延安西路65号上海国际贵都大饭店办公楼 405 单元 \\ Phone: +86-21-62489820 \\ Fax: $+86-21-62489821$
}


(C) 2011 The Author(s). Licensee IntechOpen. This is an open access article distributed under the terms of the Creative Commons Attribution 3.0 License, which permits unrestricted use, distribution, and reproduction in any medium, provided the original work is properly cited. 